\title{
Synergy between Pollution and Carbon Emissions Control: Comparing China and the United States
}

\author{
Kyung-Min Nam ${ }^{\mathrm{a},}{ }^{\dagger}$, Caleb J. Waugh ${ }^{\mathrm{b}}$, Sergey Paltsev, \\ John M. Reilly ${ }^{\mathrm{c}}$, Valerie J. Karplus ${ }^{\mathrm{d}}$
}

${ }^{a}$ Department of Urban Planning and Design, The University of Hong Kong, Pokfulam Road, Hong Kong.

${ }^{\mathrm{b}}$ NEXT Team, Lockheed Martin Corporation, 6801 Rockledge Drive, Bethesda, MD 20817 , USA.

${ }^{\mathrm{c}}$ Joint Program on the Science and Policy of Global Change, Massachusetts Institute of Technology, 77 Massachusetts Avenue, Cambridge, MA 02139, USA.

${ }^{\mathrm{d}}$ Sloan School of Management, Massachusetts Institute of Technology, 77 Massachusetts Avenue, Cambridge, MA 02139, USA.

${ }^{\dagger}$ Corresponding author.

Address: Room 707, 7/F, Knowles Building, The University of Hong Kong, Pokfulam Road, Hong Kong

Tel: (+852) 2219-4769

Fax: (+852) 2559-0468

E-mail: kmnam@hku.hk

\begin{abstract}
We estimate the potential synergy between pollution and climate control in the U.S. and China, summarizing the results as emissions cross-elasticities of control. In both countries, ancillary carbon reductions resulting from $\mathrm{SO}_{2}$ and $\mathrm{NO}_{\mathrm{x}}$ control tend to rise with the increased stringency of control targets, reflecting the eventual need for wholesale change toward non-fossil technologies when large reductions are required. Under stringent pollution targets, the non-target effects tend to be higher in China than in the U.S., due to China's heavy reliance on coal. This result suggests that China may have greater incentives to reduce $\mathrm{SO}_{2}$ and $\mathrm{NO}_{\mathrm{x}}$ with locally apparent pollution benefits, but related efforts would at the same time reduce $\mathrm{CO}_{2}$ emissions significantly. We also find strong non-target effects of $\mathrm{CO}_{2}$ abatement in both countries, but the cross effects in this direction depend less on the stringency of control and are stronger in the U.S. than in China.
\end{abstract}

Keywords: air pollution, carbon mitigation, cobenefit, emissions cross-elasticity, computable general equilibrium

JEL classifications: C68, D58, Q43, Q48, Q52, Q53, Q54, Q58 


\section{Introduction}

In this study, we explore synergistic effects of controlling emissions of nitrogen oxides $\left(\mathrm{NO}_{\mathrm{x}}\right)$ and sulfur dioxide $\left(\mathrm{SO}_{2}\right)$ and of carbon dioxide $\left(\mathrm{CO}_{2}\right)$ in the U.S. and China - the world's largest carbon emitters. The primary motivation for this research comes from the fact that $\mathrm{NO}_{\mathrm{x}}$ and $\mathrm{SO}_{2}$, two conventional air pollutants, and $\mathrm{CO}_{2}$, a primary greenhouse gas (GHG), are co-generated from combustion of fossil fuels, so their emissions are closely linked (Agee et al., 2012). The close link of emissions, in turn, suggests potential synergy between two different policiespollution abatement and carbon mitigation policies (Nam et al., 2013). Carbon-mitigation policy may achieve substantial ancillary reductions in $\mathrm{NO}_{\mathrm{x}}$ and $\mathrm{SO}_{2}$ emissions, and control of the two air pollutants may lead to a substantial ancillary cutback in carbon emissions.

We are particularly interested in the following two questions: what potential synergy exists between pollution and carbon policies in the two countries; and whether the magnitude of the synergy changes over time or depends on the stringency of emissions control. While a variety of studies have looked at the effect of carbon targets on other pollutants, our interest is to directly compare the U.S. and China using comparable methods and metrics and to examine whether and how this relationship changes with the stringency of mitigation effort. In addition to the ancillary effects of carbon reduction, we also explore unintended carbon-mitigation potential from given pollution-abatement targets. Given the difficulties of reaching international agreement on $\mathrm{CO}_{2}$, this direction of effect may be more relevant. That is, countries may be more apt to undertake efforts to control conventional pollutants because the benefits of abatement are felt more directly in the country undertaking control, and these efforts may have indirect benefits in reduced carbon pollution. 


\section{Synergy between Pollution Control and Climate Policy}

Numerous studies explore air-quality co-benefits of climate mitigation, by recognizing that conventional air pollutants and GHGs are co-generated by fossil-fuel combustion (Smith, 2013). In most cases, ancillary benefits from GHG control are estimated to be substantially large, though central estimates from different studies show a fairly high standard deviation. For example, 10 selected national co-benefits studies, placing emphasis on health benefits from unintended air-quality improvement, present a co-benefits range of $\$ 2$ to $\$ 128$ (2008 US\$) per ton of $\mathrm{CO}_{2}$ emissions mitigated (Nemet et al., 2010). In general, co-benefits estimates for developing countries tend to be larger than those for developed countries. From the review of 37 peer-reviewed studies, for example, Nemet et al. (2010) draw the mean and median co-benefits of $\$ 44 / \mathrm{tCO}_{2}$ and $\$ 31 / \mathrm{tCO}$, respectively, for the developed world and those of $\$ 81 / \mathrm{tCO}_{2}$ and $\$ 43 / \mathrm{tCO}_{2}$ for developing countries. However, cross-country comparisons of this kind suffer from differences in measures of co-benefits and methods to evaluate them, often considering different sets of air pollutants and GHGs (Bollen et al., 2009a). Apparent cross-country differences may result from different modeling approaches, pollutants considered, valuation methods, or other uncontrolled differences.

Many co-benefits studies (e.g., Bollen et al., 2009b; Rafaj et al., 2013; McCollum et al., 2013) have been motivated to convince the global community that carbon emissions control is less costly than conventionally estimated. The central logic behind this argument is that GHGreduction policy carries not only long-term benefits from mitigated climate change but also short-term benefits associated with air-quality improvement from the policy-led, reduced-use of fossil energy. However, a large part of the developing world is still skeptical about potential benefits from climate control, taking a conservative attitude toward legally binding GHG 
mitigation targets (Bodansky, 2010). In this situation, conventional pollution control may be more compelling to developing countries than policies targeting GHG mitigation directly, given that many of them confront imminent pressure to reduce local air pollution. Yet, these efforts may result in carbon reductions as an indirect or ancillary effect.

In contrast to the literature on the air-quality co-benefits of carbon reductions, the literature on the reverse - ancillary carbon benefits from pollution control—is sparse (Morgenstern et al., 2004; Nam et al., 2013; Xu and Masui, 2009). We have found only six studies exploring the latter topic (Table 1). Three of them focus on a particular city or a sector and the others are China's national-level studies without a specific sectoral focus. Despite differences in terms of focus and method, all these studies found substantial carbon-mitigation effects of pollution control, presenting the emissions cross-elasticity of $0.14-0.99$. We attempt to generalize these findings and compare the U.S. and China.

\section{Current Regulations in the U.S. and China}

In this section, we briefly review current $\mathrm{NO}_{\mathrm{x}}, \mathrm{SO}_{2}$, and $\mathrm{CO}_{2}$ regulations in the U.S. and China. In both countries, there is evidence of environmental damages from current pollution levels. These have been estimated at around 4-7\% of gross domestic product in China (World Bank and China SEPA, 2007). In the United States the impacts of degraded air quality have been the subject of numerous studies (e.g., Chay and Greenstone, 2003; Matus et al., 2008; U.S. EPA, 2011).

\section{1. $\mathrm{NO}_{\mathrm{x}}$ and $\mathrm{SO}_{2}$ Emissions Control}


Both the U.S. and China regulate air pollutant emissions, including both $\mathrm{NO}_{\mathrm{x}}$ and $\mathrm{SO}_{2}$. China's first controls on air pollution were embodied in the Air Pollution Prevention and Control Law China of 1987. Since then, China has regulated air pollution as part of its comprehensive national economic planning, which is set forth and updated through Five-Year Plans. The most recent is the Twelfth Five-Year Plan (FYP12) for the period of 2011-2015, which separately regulates emissions from the electric power sector and mobile sources. For the electric power sector, it calls for a reduction of $8 \%$ in $\mathrm{SO}_{2}$ and of $10 \%$ in $\mathrm{NO}_{\mathrm{x}}$ (which was regulated under the $\mathrm{FYP} 12$ for the first time) ( $\mathrm{Li}, 2011)$. Longer term, China's stated goal is for ambient air quality in all cities to attain the Chinese national air quality standards and similar guidelines implemented by the World Health Organization. Targets for reducing pollutant emissions include $60 \%$ for $\mathrm{SO}_{2}, 40 \%$ for $\mathrm{NO}_{\mathrm{x}}, 50 \%$ for $\mathrm{PM}_{10}$, and $40 \%$ for volatile organic compounds (VOCs) by 2050 , relative to 2005 (Wang and Hao, 2012). Efficient and cleaner use of coal and the improvement of vehicle fuel quality are major targets of regulatory efforts. Regulators have also articulated that air quality measures should be harmonized with climate policies. Many climate policy instruments, such as a carbon tax, are considered on the basis of any "green" co-benefits (Tian, 2012).

The U.S. has regulated air pollution from stationary and mobile sources under the Clean Air Act, which was first passed in 1970 and last amended in 1990 (EPA, 2013). Pollution sources are required to implement Maximum Achievable Control Technologies for each polluting activity, which are defined by the U.S. Environmental Protection Agency (EPA) and revisited every eight years. In principle, implementation of control technologies is expected to support the achievement of air quality targets, which are set forth by the U.S. National Ambient Air Quality Standards. These standards set acceptable limits for ambient levels of six "criteria" pollutants: $\mathrm{NO}_{\mathrm{x}}, \mathrm{SO}_{2}$, carbon monoxide $(\mathrm{CO})$, ozone $\left(\mathrm{O}_{3}\right)$, particulate matter $(\mathrm{PM})$, and lead. 
Areas across the U.S. are classified in terms of whether they do or do not meet the standards (attainment or non-attainment areas).

\section{2. $\mathrm{CO}_{2}$ Emissions Control}

In both the U.S. and China there is growing recognition of the need to control GHG emissions, although neither country has adopted controls on the absolute level of such emissions. China has currently pledged to reduce its carbon intensity by $40 \%$ in 2020 , relative to its 2005 level, as part of its commitment at the Copenhagen climate negotiations in 2009 (NRDC, 2009). As part of the country's FYP12, leaders are targeting a 17\% reduction in national carbon intensity, the first explicit target assigned for carbon in national law and designed to be consistent with the country's Copenhagen commitment.

The U.S. committed to reducing carbon emission by $17 \%$ below the 2005 levels by 2020 and suggested a goal of achieving an 83\% reduction by 2050 (NRDC, 2009). As of 2013, there was no legislation, executive order, regulation, or published plan explicitly dedicated to achieving these climate goals, but U.S. federal agencies and states have implemented various policies and programs to reduce GHG emissions (Damassa et al., 2012). Examples include federal regulations on vehicle fuel economy and GHG emissions standards and commercial and residential building codes, and state-driven cap-and-trade programs implemented in nine northeastern states (RGGI or the Regional Greenhouse Gas Initiative) and California (ibid.). Meanwhile the growing availability of inexpensive, domestically-produced natural gas has displaced coal in the power sector and led to a reduction in total U.S. $\mathrm{CO}_{2}$ emissions in recent years (NPR, 2012; Paltsev et al., 2011). 


\section{Method}

To explore our research questions, we have extended the MIT Emissions Prediction and Policy Analysis (EPPA5) model. Section 4.1 briefly introduces EPPA5, and Sections 4.2 and 4.3 focus on the model's carbon and pollution abatement structures.

\subsection{EPPA5}

EPPA5 is a recursive-dynamic computable general equilibrium (CGE) model, built on the Global Trade Analysis Project version 7 (GTAP7) database (Narayanan and Walmsley, 2008). This CGE model of the world economy has 16 global regions and 14 production sectors, as shown in Figure 1. In addition to economic data, EPPA5 also incorporates data for greenhouse gas $\left(\mathrm{CO}_{2}\right.$, $\mathrm{CH}_{4}, \mathrm{~N}_{2} \mathrm{O}, \mathrm{PFCs}, \mathrm{HFCs}$, and $\left.\mathrm{SF}_{6}\right)$ and urban air pollutant $\left(\mathrm{NO}_{\mathrm{x}}, \mathrm{SO}_{2}, \mathrm{CO}, \mathrm{NH}_{3}\right.$, non- $\mathrm{CH}_{4} \mathrm{VOCs}$, $\mathrm{BC}$, and $\mathrm{OC}$ ) emissions, and is capable of projecting their emissions levels, as well as gross domestic product, final demand, and energy consumption.

EPPA5 takes 2004 as the base year, and solves recursively at five-year intervals from 2005 onward. All production and final consumption sectors are modeled using nested constant elasticity of substitution production functions. The model is written in the General Algebraic Modeling System (GAMS) language and solved using the Mathematical Programming System for General Equilibrium Analysis (MPSGE) modeling framework. For further methodological details on EPPA5, refer to Paltsev et al. (2005).

A primary merit of EPPA5 is that it can easily be modified or extended for policy applications. Our modeling work for this study focuses on developing an abatement module for $\mathrm{NO}_{\mathrm{x}}$ and $\mathrm{SO}_{2}$, which corresponds to the $\mathrm{CO}_{2}$ abatement structure in the standard version of 
EPPA5. Below we briefly introduce the $\mathrm{CO}_{2}$ abatement structure of EPPA5 and the pollution abatement structure of the extended model.

\section{2. $\mathrm{CO}_{2}$ Abatement Structure in EPPA5}

EPPA5 supposes three primary channels of $\mathrm{CO}_{2}$ emissions: fossil-fuel burning, cement production, and deforestation and biomass burning. Among them, it is fossil-fuel burning that is primarily affected by an imposition of carbon caps. Thus, it matters to understand how this channel of $\mathrm{CO}_{2}$ emissions is structured in the model and how the structure responds to a policy shock.

In the model, $\mathrm{CO}_{2}$ emissions from the combustion of a fossil energy $\left(X_{E}\right)$ are proportional to the total amount of that energy source used for production $\left(X_{F}\right)$. We consider three kinds of fossil energy — coal, refined oil, and natural gas—and each of them has a constant $\mathrm{CO}_{2}$ emission factor with regard to a unit of heat energy that it generates. If a $\mathrm{CO}_{2}$ emissions cap is imposed under this structure, economic agents within the economy can switch to less $\mathrm{CO}_{2}$-intensive fossil energy sources or electricity (ELEC) or to substitute capital (or labor) for energy inputs-i.e. adoption of less carbon-intensive technology.

Carbon capture and storage (CCS) — the main ex-post carbon-abatement option—comes into play when increased prices of conventional energy inputs under policy constraints justify sizable capital investment for its adoption. $\mathrm{CCS}$ is modeled to abate not only $\mathrm{CO}_{2}$ but also $\mathrm{NO}_{\mathrm{x}}$ and $\mathrm{SO}_{2}$ emissions, as implementation of standard post-combustion CCS technology with an up to $90 \% \mathrm{CO}_{2}$ capture capability requires an additional desulfurization process prior to carbon capture, which removes over $99 \%$ of $\mathrm{NO}_{\mathrm{x}}$ and $\mathrm{SO}_{2}$ emissions from the flue gas (Deutch and Moniz, 2007). 
Figure 2 illustrates the model's fuel-related $\mathrm{CO}_{2}$ emissions structure, explained above.

\subsection{Pollution Abatement Structure in the Extended EPPA5}

We consider fuel-related and non-fuel-related pollution separately (Figure 3). On the one hand, each fuel bundle of the extended model has a fuel-related pollution sub-nest, so that fuel $\left(X_{F}\right)$, precursor emissions $\left(X_{E}\right)$, and pollution abatement $\left(X_{A}\right)$ are considered as direct production inputs. Under the Leontief production structure, each sector requires $X_{F}$ in a fixed proportion of its total output and each unit of $X_{F}$ begets a unit of $X_{E}$. We then adopt a constant elasticity of substitution (CES) production structure with the elasticity $\left(\sigma_{F u e l}\right)$ between $X_{E}$ and $X_{A}$. As $X_{A}$ is the capital cost of a unit of abatement, increasing $X_{A}$ requires additional capital, competing for investment with other capital demands. We estimate $\sigma_{\text {Fuel }}$ from the technology cost and emissions data generated by the baseline scenario of the Greenhouse Gas and Air Pollution Interactions and Synergies (GAINS) model (Nguyen et al., 2011).

Absent policy, pollution of $X_{P}$ is emitted from each activity. With policy, the level of abatement $\left(X_{A}\right)$ is determined by the stringency of pollution control and cost of abatement. In other words, emitting under pollution control creates an incentive to abate until the marginal price for abating equals the marginal price for emitting. As emitting and abating become overly costly, economic agents will shift toward less pollution-intensive fuels or reduce energy consumption to meet emissions constraints.

Non-fuel-related pollution is represented as a production input, which can be substituted by other conventional inputs, and associated pollution-abatement decisions are determined by $\sigma_{\text {Pollutant }}$. In this structure, adoption of abatement inputs results in a proportionally increased

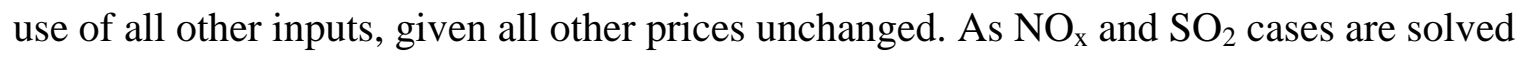


separately by sector and by fuel, the initial levels of pollution emissions and marginal abatement costs are unique to the fuel source, sector, and pollutant.

We provide further details on estimating $\sigma_{\text {Fuel }}$ and $\sigma_{\text {Pollutant }}$ in Appendix A and the full set of our estimates for the U.S. and China in Appendix B.

\section{Results}

We simulate the model developed above by imposing progressively tighter levels of nationwide emissions caps. The concept of an emissions cross-elasticity is used to summarize the ancillary reductions in the non-target emissions, $i$, resulting from a policy that targets reductions in pollutant emission $j$. As shown below, the emissions cross-elasticity $\left(\varepsilon_{i, j}\right)$ is calculated as the percentage change in emissions of $i$ between the reference $(R E F)$ and policy $(P O L)$ scenarios divided by the percentage change in emissions of $j$.

$$
\varepsilon_{i, j}=\frac{X_{i}^{R E F}-X_{i}^{P O L}}{X_{j}^{R E F}-X_{j}^{P O L}} \cdot \frac{X_{j}^{R E F}}{X_{i}^{R E F}}=\frac{\% \Delta X_{i}}{\% \Delta X_{j}}
$$

This is a simple arc elasticity comparing the total change from stringent policies with the reference pollution level. We first examine the ancillary benefits of carbon emissions reductions from $\mathrm{SO}_{2}$ and $\mathrm{NO}_{\mathrm{x}}$ policies $\left(\varepsilon_{\mathrm{CO}_{2}, \mathrm{SO}_{2}}\right.$ and $\left.\varepsilon_{\mathrm{CO}_{2}, \mathrm{NO}_{\mathrm{x}}}\right)$ and then the reverse $\left(\varepsilon_{\mathrm{NO}_{\mathrm{x}}, \mathrm{CO}_{2}}\right.$ and $\left.\varepsilon_{\mathrm{SO}_{2}, \mathrm{CO}_{2}}\right)$.

\subsection{Ancillary Carbon Benefits of $\mathrm{SO}_{2}$ and $\mathrm{NO}_{x}$ Control}

We simulate a total of five scenarios. One is a baseline scenario, which we call $R E F$. In this scenario, we do not impose any further policy constraint beyond existing $\mathrm{NO}_{\mathrm{x}}$ and $\mathrm{SO}_{2}$ emissions regulations. $\mathrm{NO}_{\mathrm{x}}$ and $\mathrm{SO}_{2}$ emissions schedules for the U.S. and China under the REF scenario are displayed in Figure 4. The other four are policy scenarios imposing progressively tighter 
reduction targets for $\mathrm{NO}_{\mathrm{x}}$ and $\mathrm{SO}_{2}$ emissions at the national level. We simulate these reductions over the period of 2015-2050. The scenarios cap emissions at $10 \%, 25 \%, 50 \%$, or $75 \%$ reductions from the baseline $\mathrm{NO}_{\mathrm{x}}$ and $\mathrm{SO}_{2}$ emissions levels. The EPPA model solves every 5 years, and we compute the cross-elasticities for each reduction level and for each solution year. This setup allows us to evaluate (1) how ancillary carbon benefits differ for $\mathrm{SO}_{2}$ and $\mathrm{NO}_{\mathrm{x}}$ control, (2) how they vary over time, and (3) how they change as the stringency of control efforts varies. We set the policy targets relative to the reference emissions levels, instead of imposing constant emissions caps, so that we have comparable reductions in China and the U.S. Emissions of all pollutants are growing rapidly in China and slowly in the U.S., and hence an absolute cap relative to a historic year would imply much greater percentage reductions in China over time than in the U.S., conflating any time trend with changes in the stringency of reduction.

Our results present several common tendencies in each country (Tables $\mathbf{2}$ and 3). First, $\varepsilon_{\mathrm{CO}_{2}, \mathrm{NO}_{\mathrm{x}}}$ and $\varepsilon_{\mathrm{CO}_{2}, \mathrm{SO}_{2}}$ are comparable, in terms of magnitude, although the former tend to be slightly higher than the latter. $\varepsilon_{\mathrm{CO}_{2}, \mathrm{NO}_{\mathrm{x}}}$ shows ranges of $0.12-0.67$ in the U.S. and $0.06-1.03$ in China; similarly, $\varepsilon_{\mathrm{CO}_{2}, \mathrm{SO}_{2}}$ shows ranges of $0.11-0.54$ in the U.S. and $0.08-0.93$ in China. This outcome is primarily because $\mathrm{NO}_{\mathrm{x}}$ and $\mathrm{SO}_{2}$ emissions share similar sources, such as fossil-fuel combustion or energy-intensive production. Both $\varepsilon_{\mathrm{CO}_{2}, \mathrm{NO}_{\mathrm{x}}}$ and $\varepsilon_{\mathrm{CO}_{2}, \mathrm{SO}_{2}}$ tend to be greater under more stringent pollution-control targets. Under the $10 \% \mathrm{NO}_{\mathrm{x}}$ reduction targets, for example, $\varepsilon_{\mathrm{CO}_{2}, \mathrm{NO}_{\mathrm{x}}}$ shows ranges of $0.12-0.23$ in the U.S. and of $0.06-0.13$ in China, but the $75 \%$ targets drive up the ranges to $0.59-0.61$ for the U.S. and 0.94-1.03 for China. This coincides with our expectation, as stringent pollution-control targets make pollution-abatement options costly and increase the need for cutting energy use - particularly, fossil fuel use.

While the general relationships are similar across countries, China tends to show higher 
$\varepsilon_{\mathrm{CO}_{2}, \mathrm{NO}_{\mathrm{x}}}$ and $\varepsilon_{\mathrm{CO}_{2}, \mathrm{SO}_{2}}$ than the U.S. under stringent targets. Under the $75 \%$ targets, for example, $\varepsilon_{\mathrm{CO}_{2}, \mathrm{SO}_{2}}$ in China shows a range of $0.83-0.93$, roughly twice as high as that in the U.S.

$(0.40-0.47)$. This contrasts the $10 \%$ target case, where $\varepsilon_{\mathrm{CO}_{2}, \mathrm{SO}_{2}}$ is slightly higher in the U.S. $(0.11-0.15)$ than in China (0.08-0.11). As will be explained in detail, this fact is closely related to China's higher dependency on coal. The time trend of the elasticities in each emission control scenario also differs by country. In brief, both $\varepsilon_{\mathrm{CO}_{2}, \mathrm{NO}_{\mathrm{x}}}$ and $\varepsilon_{\mathrm{CO}_{2}, \mathrm{SO}_{2}}$ in China present declining tendencies over time, while those in the U.S. show increasing or constant trends. This is primarily because $\mathrm{NO}_{\mathrm{x}}$ and $\mathrm{SO}_{2}$ baseline emissions, which continue to grow over time in China, allow China to have more room to comply with the given policy without reducing energy use in later time periods. In contrast, $\mathrm{NO}_{x}$ and $\mathrm{SO}_{2}$ baseline emissions in the U.S. grow only marginally over time, leading to relatively constant cross effects over time.

Each simulation run for the results introduced above constrains either $\mathrm{NO}_{\mathrm{x}}$ or $\mathrm{SO}_{2}$, but in reality, China is likely to regulate the two pollutants at the same time. Thus, we developed a new set of policy simulations where limits are set on both pollutants, and this case is denoted as POLL. The elasticity denoted as $\varepsilon_{\mathrm{CO}_{2} \text {,POLL }}$ refers to the percentage change of $\mathrm{CO}_{2}$ emissions driven by a unit percent change of $\mathrm{NO}_{\mathrm{x}}$ and $\mathrm{SO}_{2}$ emissions due to targeting reductions in both pollutants together.

As illustrated in Figure 5, $\varepsilon_{\mathrm{CO}_{2} \text {,POLL }}$ presents trends similar to those of $\varepsilon_{\mathrm{CO}_{2}, \mathrm{NO}_{\mathrm{x}}}$ and $\varepsilon_{\mathrm{CO}_{2}, \mathrm{SO}_{2}}$. The stringency of the policy shock is positively associated with the elasticity in each country, and China tends to show substantially higher $\varepsilon_{\mathrm{CO}_{2}, \mathrm{POLL}}$ than the U.S. when targets are stringent.

However, two puzzling aspects are found in the same figure. One is why in the U.S. $\varepsilon_{\mathrm{CO}_{2} \text {,POLL }}$ presents lower values under the $75 \%$ reduction targets than the $50 \%$ case in 2030 and 
thereafter. As hinted earlier, the answer is closely related to the changed mix of energy demand in the presence of policy shocks. Due to its high emission factors, coal is affected more greatly by $\mathrm{NO}_{\mathrm{x}}$ and $\mathrm{SO}_{2}$ regulations than other fossil energy sources. We see an increasing role of other energy sources in meeting the given emissions-reduction targets, as energy demand from coal converges to the minimal level that an economy can afford (Figure 6). Under the $75 \%$ targets, for example, the U.S. is expected to remove over $98 \%$ of its baseline coal use by 2025 and to comply with the policy by cutting an increased portion of energy demand from refined oil and natural gas since then (Figure 7). The reduced role of coal and the expanded role of refined oil and natural gas in policy compliance cases lowers cross-elasticities of $\mathrm{SO}_{2}$ and $\mathrm{NO}_{\mathrm{x}}$ control, leading to the relatively sharp decline of $\varepsilon_{\mathrm{CO}_{2}, \mathrm{POLL}}$ in 2030 , even below the $50 \%$ target level. The $50 \% \varepsilon_{\mathrm{CO}_{2}, \mathrm{POLL}}$ line for the U.S. suddenly rises in 2030 because a large cut in coal use in the electricity sector is achieved through increased substitution of the natural gas combined cycle (NGCC) for conventional coal-fired power-generation technology (Figure 8).

The other puzzling trend found in Figure 5 is why $\varepsilon_{\mathrm{CO}_{2}, \mathrm{POLL}}$ for China presents an increasing tendency over time under the $75 \%$ targets, and a slightly falling trend over time for other reduction targets. This trend is related to the relative magnitude of the policy constraint imposed in each time period. Due to constantly growing baseline emission levels, China tends to have increasing flexibility over time under each policy scenario, in terms of choosing policycompliance options beyond a cutback of energy use. Under the $10 \%$ targets, for example, avoided energy demand reductions through adoption of pollution-abatement technology increase over time from 6.7 EJ in 2015 to $20.3 \mathrm{EJ}$ in 2050 (Figure 6c). Accordingly, China can comply with the $10 \%$ targets without increasing the absolute amount of energy demand reductions in later periods. Due to this increasing flexibility, in terms of response to a given policy shock, 
$\varepsilon_{\mathrm{CO}_{2}, \mathrm{POLL}}$ for China tends to decline over time under relatively moderate targets.

However, this is not the case under the $75 \%$ targets, where China confronts increasingly strong pressure for energy demand reductions over time. This is because the increased stringency of policy shock leaves China limited room for other pollution-abatement options and instead energy use itself is reduced (Figure 6d). China’s electricity output mix, shown in Figure 9, clearly demonstrates our argument: as complying with the $50 \%$ or lower reduction targets presents a smooth and gradual coal-use reduction schedule but the $75 \%$ reduction targets lead to a more drastic change in output mix, requiring much greater reduction of coal use and more intensive adoption of cleaner technologies, such as advanced nuclear ${ }^{1}$ and wind power with back-up capacity from natural gas (wind-gas). In contrast to the corresponding U.S. case, however, China still has capacity to cut its coal use under the $75 \%$ targets. The $75 \%$ targets completely phase out coal from China’s electricity sector by 2040 (Figure 9), but substantial amounts of coal (12-14 EJ) are still used by non-electricity sectors, most notably energyintensive industries ${ }^{2}$ and households (Figure 7b). Capacity for further reduction of coal use, as well as increased pressure for fossil-energy use reduction (due to limited opportunities for abatement-technology adoption), contributes to an increasing trend of $\varepsilon_{\mathrm{CO}_{2} \text {,POLL }}$ over time under the $75 \%$ targets.

\subsection{Ancillary Air Quality Benefits of $\mathrm{CO}_{2}$ Mitigation}

We also simulated a reference and four climate policy scenarios for a cross-country comparison of ancillary $\mathrm{NO}_{\mathrm{x}}$ and $\mathrm{SO}_{2}$ reductions from carbon mitigation. Figure $\mathbf{1 0}$ displays $\mathrm{CO}_{2}$ emissions

\footnotetext{
${ }^{1}$ Advanced nuclear refers to generation 3+ nuclear technologies based on reprocessing or breeder-type fuel cycles.

${ }^{2}$ Energy-intensive industries (EINT) in EPPA5 include the sectors that produce paper products, chemical products, ferrous and non-ferrous metals, metal products, and mineral products.
} 
schedules for the U.S. and China under the REF scenario. We set a range of $\mathrm{CO}_{2}$ reduction targets- $-10 \%, 25 \%, 50 \%$, or $75 \%$ reductions from the baseline levels - and recorded ancillary $\mathrm{NO}_{\mathrm{x}}$ and $\mathrm{SO}_{2}$ reductions to compute emissions cross-elasticities.

In general, $\varepsilon_{\mathrm{NO}_{\mathrm{x}}, \mathrm{CO}_{2}}$ and $\varepsilon_{\mathrm{SO}_{2}, \mathrm{CO}_{2}}$ tend to be much higher than $\varepsilon_{\mathrm{CO}_{2}, \mathrm{NO}_{\mathrm{x}}}$ and $\varepsilon_{\mathrm{CO}_{2}, \mathrm{SO}_{2}}$ at low levels of abatement, but increase more gradually with the level of abatement (Tables 4 and 5). For example, $\varepsilon_{\mathrm{NO}_{x}, \mathrm{CO}_{2}}$ shows ranges of $0.43-0.78$ in the U.S. and $0.29-0.45$ in China under the $10 \%$ reduction targets. The ranges go up to $0.60-0.85$ and $0.41-0.65$, respectively, under the $75 \%$ targets. This result can be attributed to the increased stringency of a policy shock leaving little room for fuel switching, placing a greater pressure for energy demand reduction on an economy. In both countries, $\varepsilon_{\mathrm{SO}_{2}, \mathrm{CO}_{2}}$ presents slightly higher values than $\varepsilon_{\mathrm{NO}_{\mathrm{x}}, \mathrm{CO}_{2}}$.

Both $\varepsilon_{\mathrm{NO}_{\mathrm{x}}, \mathrm{CO}_{2}}$ and $\varepsilon_{\mathrm{SO}_{2}, \mathrm{CO}_{2}}$ are substantially higher in the U.S. than in China under all policy scenarios, presenting a clear contrast to $\varepsilon_{\mathrm{CO}_{2}, \mathrm{NO}_{\mathrm{x}}}$ and $\varepsilon_{\mathrm{CO}_{2}, \mathrm{SO}_{2}}$. For the given $10-75 \% \mathrm{CO}_{2}$ reduction targets, $\varepsilon_{\mathrm{NO}_{x}, \mathrm{CO}_{2}}$ shows ranges of $0.43-0.85$ in the U.S. and of 0.29-0.65 in China; $\varepsilon_{\mathrm{SO}_{2}, \mathrm{CO}_{2}}$ is distributed between 0.74 and 1.30 in the U.S. and between 0.34 and 0.74 in China. The stronger cross effects in the U.S. are because a policy shock of comparable stringency requires the U.S. to cut a relatively large amount of coal use, as suggested by baseline carbon emissions schedules in Figure 10. The carbon constraint is met primarily through fuel switching, reduction of energy consumption, and adoption of CCS and non-fossil energy technologies. All these responses entail relatively large reductions in coal use, compared with other fossil energy use, due to coal's higher carbon content. Under the $25 \%$ reduction targets, for example, around half the total energy-use reduction in the U.S. is from coal; the corresponding share for China is even higher, ranging from 64.6-74.7\%, due to China's higher dependence on coal (Figure 11a and b). In relative terms, however, comparable carbon-mitigation targets induce more drastic cuts in coal 
use (from the baseline levels) in the U.S. than in China. Under the $25 \%$ targets, for example, the U.S. is estimated to reduce $37.6-45.6 \%$ of its baseline coal consumption (8.7-12.3 EJ), while China is estimated to reduce 28.3-29.0\% (21.4-46.7 EJ) (Figure 11c). A greater magnitude of coal use reduction in the U.S., in turn, results in higher cross-elasticities for the U.S.

In some cases, the cross effects deviate from the given general trends, as exemplified by $\varepsilon_{\mathrm{SO}_{2}, \mathrm{CO}_{2}}$ for the U.S. As illustrated in Figure 12, a consistent relationship between cross-elasticity and policy stringency does not hold for the U.S., in contrast to the case of China, where the level of $\varepsilon_{\mathrm{SO}_{2}, \mathrm{CO}_{2}}$ increases as carbon reduction targets become more stringent. This result is in part explained by policy-driven changes in coal consumption (Figure 13). The U.S. $\varepsilon_{\mathrm{SO}_{2}, \mathrm{CO}_{2}}$ line for the $75 \%$ target case is located below that for the $50 \%$ case because coal completely exits the market from the initial year of carbon constraint under the $75 \%$ targets, while demand for coal remains under the $50 \%$ targets until 2025. In other words, a larger share of the total energy demand reduction is from oil and gas under the $75 \%$ targets - thus, leading to relatively lower pollution-abatement effects - than under the $50 \%$ targets. In contrast, even the $75 \%$ carbon reduction policy does not drive coal completely out of China's energy market, causing less drastic changes in the trend of cross-elasticities. Again, this is because under the reference case scenario China's fossil energy use is growing relatively fast while there is limited growth in the U.S.

But the remaining puzzle is why part of the cross-elasticities for the $75 \%$ reduction targets in the U.S. remain below the elasticities for the $10 \%$ and $25 \%$ targets in later periods. A focus on the electricity sector is helpful to understand why this happens, as it is the single most important production sector in complying with carbon-mitigation targets in the U.S. (Figure 14). First, the $10 \%$ targets are not stringent enough to incentivize adoption of low carbon technology, 
such as NGCC, so the targets are met primarily through fuel switching and less use of energy

(Figure 15). The 25\% targets, however, allow NGCC to penetrate the market, and its substitution for coal-fired power generation technology achieves a relatively large reduction of coal use, compared with the reduction under the $10 \%$ targets. Therefore, the cross-elasticities for the $25 \%$ targets tend to be higher than those for the $10 \%$ targets. Under the $50 \%$ targets, NGCC and other clean energy technologies, such as advanced nuclear and wind-gas, are competitive in the market and crowd out conventional coal at a rapid pace. The cross-elasticities for the $50 \%$ targets are greater than those for the $10 \%$ and $25 \%$ targets in later periods, as the $50 \%$ targets drive conventional coal completely out of the market in 2030 and later periods while the $10 \%$ and $25 \%$ targets allow gradual increase of coal use.

Finally, the $75 \%$ targets completely crowd out conventional coal-fired power-generation technology from 2015, allowing expanded roles of advanced nuclear and wind-gas. But reduction of fossil energy use in the electricity sector alone is not enough to comply with the policy; further energy use reduction should come from other sectors, which in general depend on coal less than the electricity sector does. As shown in Figure 14, the $75 \%$ targets in particular require increased energy demand reduction from the household sector, which mainly consumes refined oil and natural gas for vehicle operations and heating. Thus, the cross-elasticities are relatively low under the $75 \%$ targets, compared with other cases. However, the elasticities for the $75 \%$ targets catch up with those for the $10 \%$ and $25 \%$ targets in later periods and eventually overtake them, as the $10 \%$ and $25 \%$ targets allow gradual increase of coal use over time while the $75 \%$ targets do not.

Compared to the U.S., China shows a much smoother transition in electricity output mix (Figure 16). With increased stringency of carbon reduction targets, conventional coal 
technologies gradually phase out of the electricity sector, and part of the reduced coal-fired power output is increasingly replaced by less emissions-intensive alternatives, such as coal-fired power generation combined with CCS (coal with CCS) and wind power with backup capacity from biomass (wind-biomass). This smoother transition in the electricity sector explains why China displays more consistent trends of $\varepsilon_{\mathrm{NO}_{\mathrm{x}}, \mathrm{CO}_{2}}$ and $\varepsilon_{\mathrm{SO}_{2}, \mathrm{CO}_{2}}$, in response to increased stringency of policy shock, than the U.S. does.

\section{Conclusions}

In this study, we first introduce an analytic framework for pollution-climate control synergy and then apply the methodology to the U.S. and China. The primary contributions of this study to the literature and the policy debate include the following three aspects. First, our analysis is based on a new methodological approach, which endogenizes pollution emissions-abatement decisions within a CGE structure, incorporating bottom-up engineering details. This is a substantial improvement on conventional methods assuming fixed emission factors or exogenous abatement opportunities. Second, our study enriches the literature on ancillary carbon benefits of pollution abatement, which is sparse despite growing attention to the topic. Finally, our results, summarized as emissions cross-elasticities, provide the basis for a parallel comparison of the U.S. and China, in terms of ancillary $\mathrm{CO}_{2}$ reductions from $\mathrm{NO}_{\mathrm{x}}$ and $\mathrm{SO}_{2}$ targets or of ancillary $\mathrm{NO}_{\mathrm{x}}$ and $\mathrm{SO}_{2}$ reductions from $\mathrm{CO}_{2}$ targets.

In general, higher stringency of pollution-abatement targets is associated with greater

cross-elasticities of pollution control. For $\varepsilon_{\mathrm{CO}_{2}, \mathrm{NO}_{\mathrm{x}}}$ and $\varepsilon_{\mathrm{CO}_{2}, \mathrm{SO}_{2}}$, we find low values (0.06-0.23) in both countries with the $10 \%$ reduction targets, but they rise to $0.40-0.67$ in the U.S. and to 0.83-1.03 in China under the 75\% targets. The key mechanism underlying this result is that 
increased costs for abatement-technology adoption and fuel switching under stringent targets incentivize economic agents to shift toward energy-consumption reductions and advanced energy-technology implementation, having greater effects on carbon emissions. That is, this tendency reflects the availability of pollution control to target individual pollutants for smaller reductions but the need for wholesale change toward non-fossil technologies when large reductions are required. The especially high cross-elasticities in China under stringent targets are due to the interplay between increased pressure for energy input reduction and China's high dependence on coal. Meeting stringent targets in both countries requires a massive reduction of energy use, but a larger share of the total energy use reduction in China is from coal. This relatively larger reduction of coal use leads to greater ancillary carbon reductions in China, translating into higher cross-elasticities.

A similar trend is found from the opposite experiment. Both $\varepsilon_{\mathrm{SO}_{2}, \mathrm{CO}_{2}}$ and $\varepsilon_{\mathrm{NO}_{\mathrm{X}}, \mathrm{CO}_{2}}$, in general, tend to increase with increased stringency of carbon reduction targets. For example, $\varepsilon_{\mathrm{NO}_{x}, \mathrm{CO}_{2}}$ presents ranges of $0.43-0.78$ in the U.S. and $0.29-0.45$ in China under the $10 \%$ targets, but the $75 \%$ targets drive up the ranges to $0.60-0.85$ and $0.41-0.65$, respectively. In some cases, however, the cross-elasticities in the U.S. deviate from this general trend, depending on the role of advanced energy technologies. In addition, both $\varepsilon_{\mathrm{SO}_{2}, \mathrm{CO}_{2}}$ and $\varepsilon_{\mathrm{NO}_{x}, \mathrm{CO}_{2}}$ are much greater in the U.S. than in China, presenting a clear contrast to $\varepsilon_{\mathrm{CO}_{2}, \mathrm{NO}_{\mathrm{x}}}$ and $\varepsilon_{\mathrm{CO}_{2}, \mathrm{SO}_{2}}$. The magnitude of coal use reductions from the baseline levels is a main source of this result. In general, meeting $\mathrm{CO}_{2}$ reduction targets of comparable stringency leads to more drastic reduction of coal use in the U.S. (partly through more intensive adoption of low carbon technology), generating greater cross effects in the U.S. than in China. 
In sum, our results demonstrate substantial cross effects between the two conventional air pollutants and carbon dioxide in both directions and in both countries. The majority of existing studies have focused on the effect of $\mathrm{CO}_{2}$ abatement on other pollutants, typically finding strong cross effects, but we also found evidence for similarly strong ancillary carbon-mitigation effects of pollution control. The latter result, in particular, seems to offer some hope that carbon emissions may not increase as much as some forecasts suggest if concerns about conventional pollutants lead to policies to reduce them. Our study of China presents a strong effect on carbon emissions of efforts to reduce $\mathrm{SO}_{2}$ and $\mathrm{NO}_{\mathrm{x}}$. The U.S. and China are both relatively coalintensive economies. Given that other economies are less so, we may well see different relationships between control of conventional pollutants and $\mathrm{CO}_{2}$. It would be interesting to follow up this research for other regions of the world.

\section{Acknowledgments}

The authors are grateful to Howard Herzog and Henry Chen for their valuable inputs for this study. We acknowledge the support of the French Development Agency (AFD), ENI, ICF International, and Shell, founding sponsors of the China Climate and Energy Project, for this application of the EPPA model, and BP's support of Caleb Waugh's thesis, which provided the

foundation work for representing air pollution control in the EPPA model. We also acknowledge general industrial and government sponsors of the Joint Program on the Science and Policy of Global Change (http://globalchange.mit.edu/sponsors/all), including the DOE Integrated Assessment Grant (DE-FG02-94ER61937), through which we have developed and maintain the EPPA modeling framework. 


\section{References}

Agee, M.D., Atkinson, S.E., Crocker, T.D., Williams, J.W., 2012. Non-Separable Pollution Control: Implications for a $\mathrm{CO}_{2}$ Emissions Cap and Trade System. Available at http://dx.doi.org/10.2139/ssrn.2201652.

Bodansky, D., 2010. The Copenhagen Climate Change Conference: A Postmortem. American Journal of International Law 104(2), 230-240.

Bollen, J., Guay, B., Jamet, S., Corfee-Morlot, J., 2009a. Co-benefits of Climate Change Mitigation Policies. Organisation for Economic Co-operation and Development, Paris.

Bollen, J., van der Zwaan, B., Brink, C., Eerens, H., 2009b. Local Air Pollution and Global Climate Change: A Combined Cost-benefit Analysis. Resource and Energy Economics 31(3), 161-181.

Cao, J., Ho, M.S., Jorgenson, D., 2012. An Integrated Assessment of the Economic Costs and Environmental Benefits of Pollution and Carbon Control, in: Aoki, M., Wu, J. (Eds.), The Chinese Economy: A New Transition. Palgrave Macmillan, New York, NY.

Chae, Y., 2010. Co-benefit Analysis of an Air Quality Management Plan and Greenhouse Gas Reduction Strategies in the Seoul Metropolitan Area. Environmental Science and Policy 13, 205-216.

Chay, K.Y., Greenstone, M., 2003. The Impact of Air Pollution on Infant Mortality: Evidence from Geographic Variation in Pollution Shocks Induced by a Recession. Quarterly Journal of Economics 118(3), 1121-1167.

Damassa, T., Bianco, N., Fransen, T., 2012. GHG Mitigation in the United States: An Overview of the Current Policy Landscape. World Resources Institute, Washington, DC.

EPA (U.S. Environmental Protection Agency), 2011. The Benefits and Costs of the Clean Air Act from 1990 to 2020. EPA, Washington, DC. Available at http://www.epa.gov/oar/sect812/prospective2.html.

EPA (U.S. Environmental Protection Agency), 2013. Summary of the Clean Air Act. 42 U.S.C. $\S 7401$ et seq. (1970). Available at http://www.epa.gov/regulations/laws/caa.html.

Hao, J., Wang, S., 2012. Air Quality Management in China: Issues, Challenges, and Options. Journal of Environmental Sciences 24(1), 2-13.

Li, J., 2011. Emission Rules Get Tougher. China Daily, September 9.

Matus, K., Yang, T., Paltsev, S., Reilly, J., Nam, K.-M., 2008. Toward Integrated Assessment of Environmental Change: Air Pollution Health Effects in the USA. Climatic Change 88(1), 59-92.

Matus, K., Nam, K.-M., Selin, N.E., Lamsal, L.N., Reilly, J.M., Paltsev, S., 2012. Health Damages from Air Pollution in China. Global Environmental Change 22(1), 55-66.

McCollum, D.L., Krey, V., Riahi, K., Kolp, P., Grubler, A., Makowski, M., Nakicenovic, N., 2013. Climate Policies Can Help Resolve Energy Security and Air Pollution Challenges. Climatic Change 119, 479-494.

Meadows, D., Randers, J., Meadows, D., 2004. Limits to Growth: The 30-Year Update. Chelsea Green, White River Junction, VT.

Metz, B., Davidson, O.R., Bosch, P.R., Dave, R., Meyer, L.A. (Eds.), 2007. Climate Change 2007: Mitigation of Climate Change. Cambridge University Press, Cambridge.

Morgenstern, R., Krupnick, A., Zhang, X., 2004. The Ancillary Carbon Benefits of $\mathrm{SO}_{2}$ Reductions from a Small-boiler Policy in Taiyuan, PRC. Journal of Environment and Development 13(2), 140-155. 
Nam, K.-M., Waugh, C.J., Paltsev, S., Reilly, J.M., Karplus, V.J., 2013. Climate Co-benefits of Tighter $\mathrm{SO}_{2}$ and $\mathrm{NO}_{\mathrm{x}}$ Regulations in China. Global Environmental Change (forthcoming), doi: 10.1016/j.gloenvcha.2013.09.003.

Narayanan, B., Walmsley, T.L., 2008. Global Trade, Assistance, and Production: The GTAP v7 Data Base. Purdue University, Center for Global Trade Analysis, West Lafayette, IN.

Nemet, G.F., Holloway, T., Meier, P., 2010. Implications of Incorporating Air-quality Cobenefits into Climate Change Policymaking. Environmental Research Letters 5, 014007 (9pp).

Nguyen, T.B., Wagner, F., Schoepp, W., 2011. GAINS - An Interactive Tool for Assessing International GHG Mitigation Regimes, in: Kranzlmüller, D., Tjoa, A.M. (Eds.), Information and Communication on Technology for the Fight against Global Warming. Springer, Toulouse.

Nielsen, C.P., Ho, M.S., 2007. Air Pollution and Health Damages in China: An Introduction and Review, in: Ho, M.S., Nielsen, C.P. (Eds.), Clearing the Air: The Health and Economic Damages of Air Pollution in China. MIT Press, Cambridge, MA.

NPR (U.S. National Public Radio), 2012. From Coal to Gas: The Potential Risks and Rewards. Available at http://www.npr.org/2012/07/15/156814490/from-coal-to-gas-the-potentialrisks-and-rewards.

NRDC (National Resources Defense Council), 2009. From Copenhagen Accord to Climate Action: Tracking National Commitments to Curb Global Warming. Available at http://www.nrdc.org/international/copenhagenaccords.

Paltsev, S., Jacoby, H.D., Reilly, J.M., Ejaz, Q.J., Morris, J., O'Sullivan, F., Rausch, S., Winchester, N., Kragha, O., 2011. The Future of U.S. Natural Gas Production, Use, and Trade. Energy Policy 39(9), 5309-5321.

Paltsev, S., Reilly, J.M., Jacoby, H.D., Eckaus, R.S., McFarland, J., Sarofim, M., Asadoorian, M., Babiker, M., 2005. The MIT Emissions Prediction and Policy Analysis (EPPA) Model: Version 4, MIT JPSPGC. MIT Joint Program on the Science and Policy of Global Change, Cambridge, MA. Available at http://globalchange.mit.edu/files/document/MITJPSPGC_Rpt125.pdf.

Rafaj, P., Schöpp, W., Russ, P., Heyes, C., Amann, M., 2013. Co-benefits of Post-2012 Global Climate Mitigation Policies. Mitigation and Adaptation Strategies for Global Change 18, 801-824.

Smith, A., 2013. The Climate Bonus: Co-benefits of Climate Policy. Routledge, New York, NY. Tian, W., 2012. Officials Weighing Green Benefits of Carbon Taxation. China Daily, January 6. van Aardenne, J., Monni, S., Olivier, J., Doering, U., Orlandini, L., Pagliari, V., Peters, F., Sanmartin, F., Maenhout, G., 2009. Emissions Dataset for Global Atmospheric Research (EDGAR), release 4.0. European Comission, Joint Research Center (JRC) and Netherlands Environmental Assesment Agency (PBL). Available at http://edgar.jrc.ec.europa.eu.

Wang, S., Hao, J., 2012. Air Quality Management in China: Issues, Challenges, and Options. Journal of Environmental Sciences 24(1), 2-13.

World Bank, 2012. World Development Indicators Online. World Bank, Washington, D.C. Available at http://publications.worldbank.org/WDI.

World Bank, SEPA (P.R.C. State Environmental Protection Administration), 2007. Cost of Pollution in China: Economic Estimates of Physical Damages. World Bank, Washington, D.C.

Xu, Y., Masui, T., 2009. Local Air Pollutant Emission Reduction and Ancillary Carbon Benefits 
of $\mathrm{SO}_{2}$ Control Policies: Application of AIM/CGE Model to China. European Journal of Operational Research 198, 315-325. 


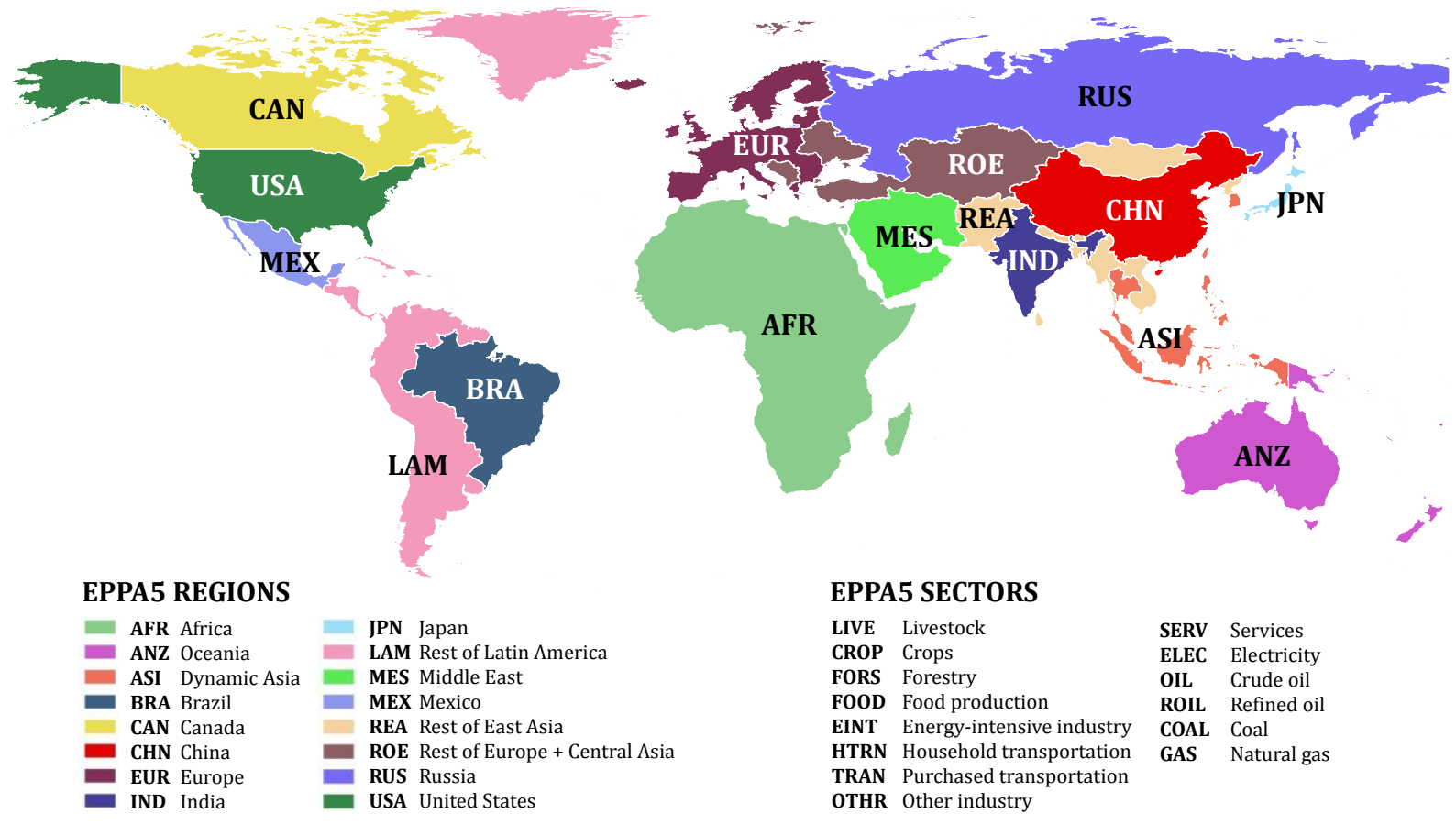

Figure 1. Regional and Sectoral Aggregation Schemes in EPPA5. Source: Nam et al. (2013), p. 1649. 


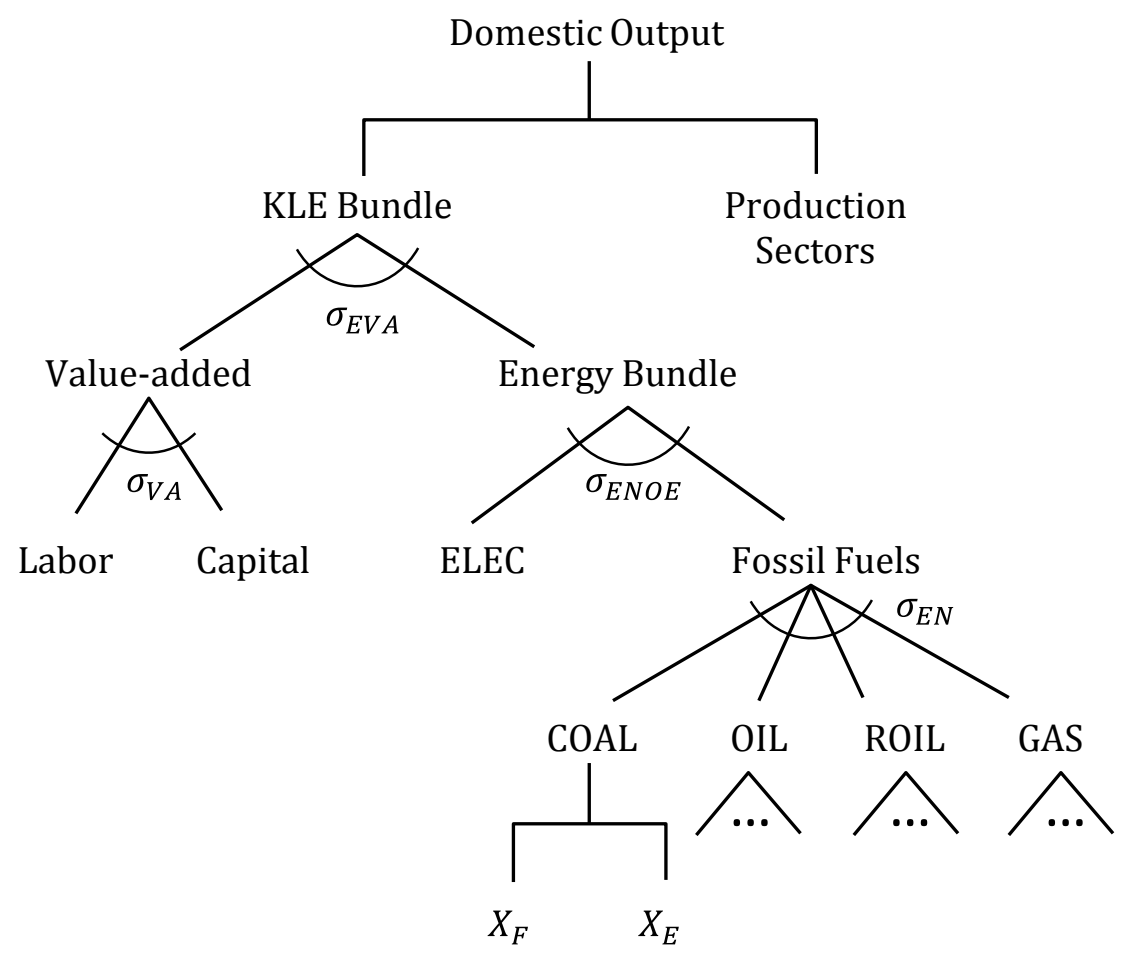

Figure 2. Fuel-related $\mathrm{CO}_{2}$ emissions structure in EPPA5. Source: Modified from Paltsev et al. (2005), p. 18. 
(a)

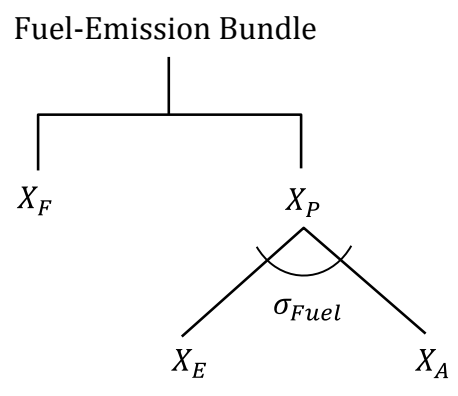

(b)

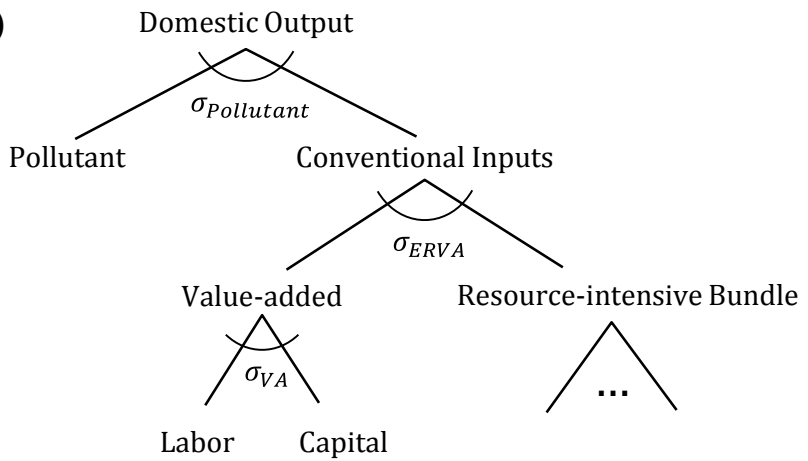

Figure 3. Pollution abatement structure: (a) Fuel-related pollution, (b) Non-fuel-related pollution. Source: Adopted from Nam et al. (2013), p. 1650. 

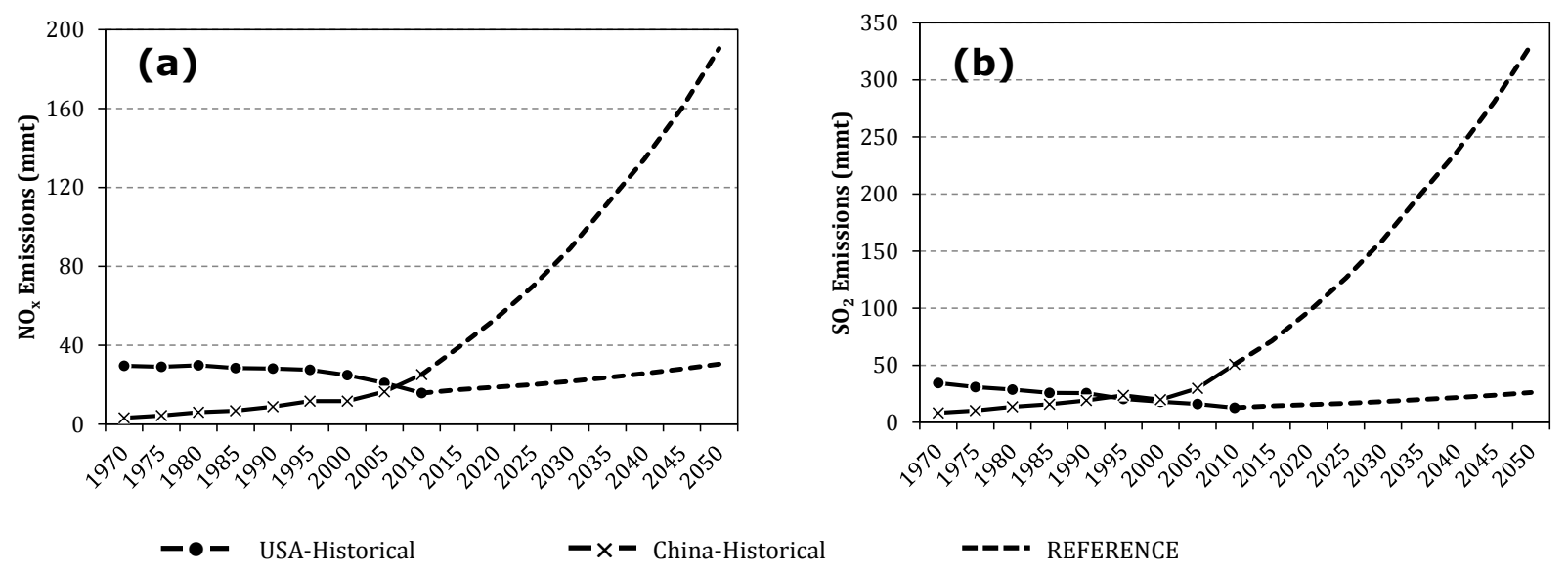

Figure 4. Baseline emissions schedule: (a) $\mathrm{NO}_{\mathrm{x}}$ (b) $\mathrm{SO}_{2}$. 

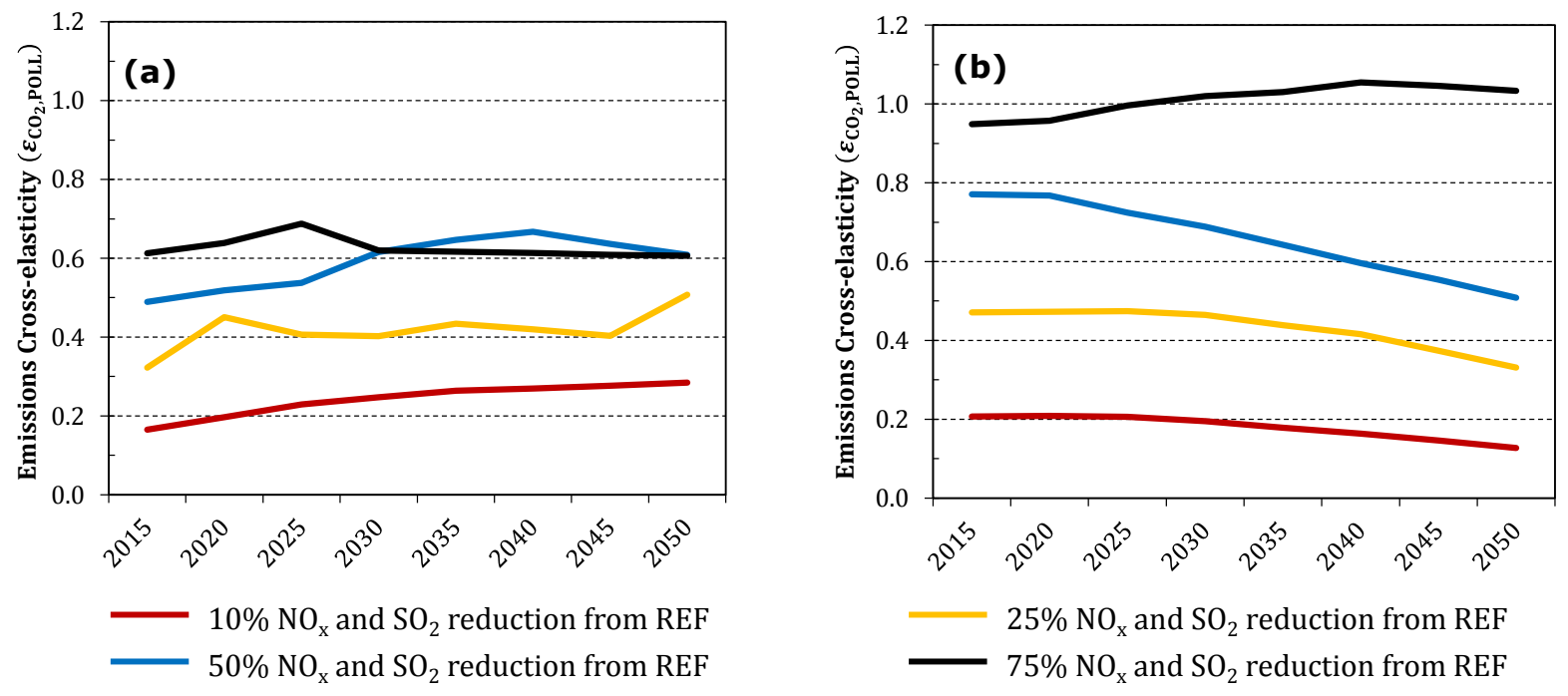

Figure 5. Cross emissions elasticity $\left(\boldsymbol{\varepsilon}_{\mathrm{CO}_{2}, \mathrm{POLL}}\right)$ by scenario: (a) U.S., (b) China. 

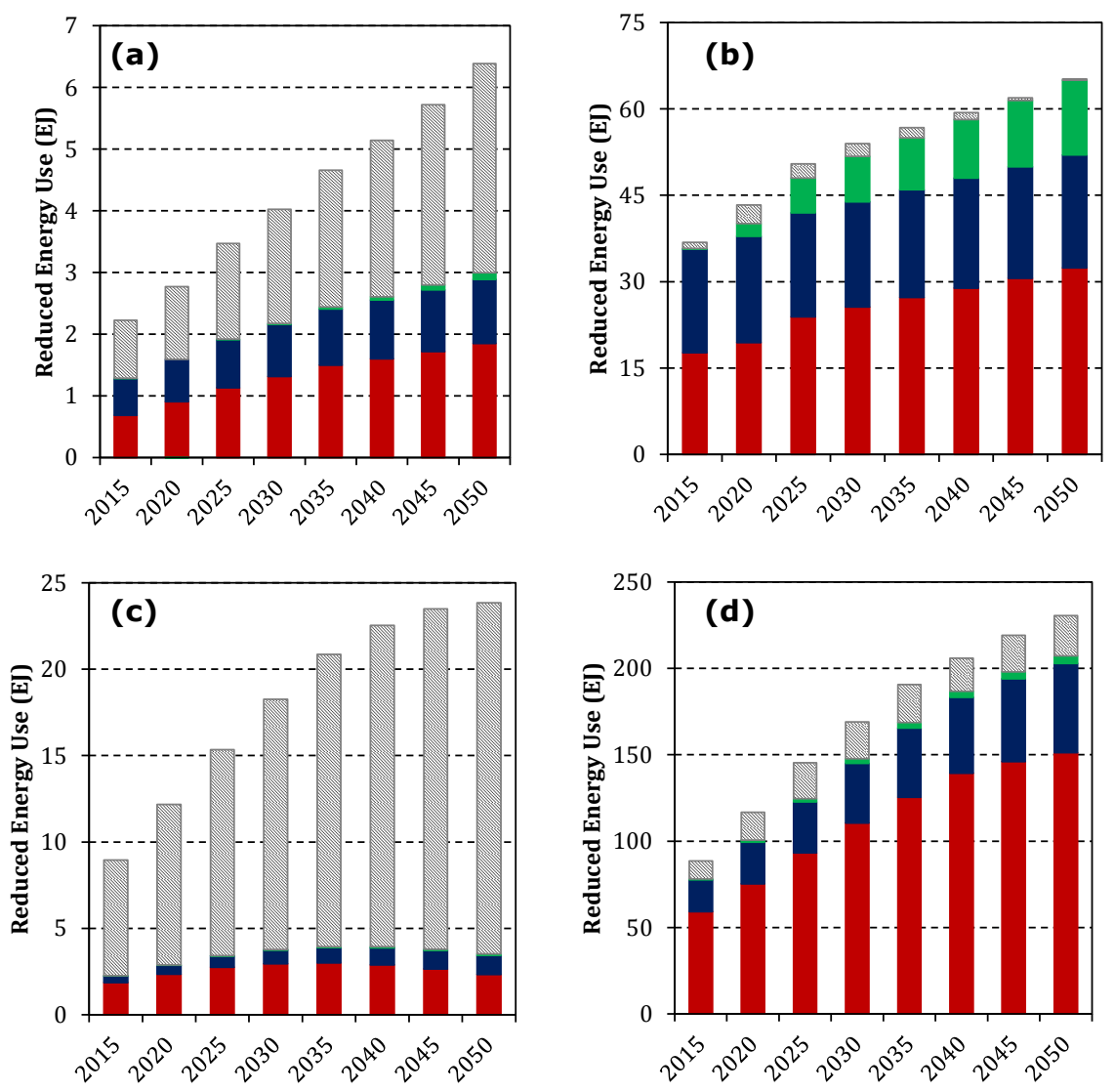

Energy demand reduction avoided through adoption of pollution-abatement technology

Coal

Refined oil

Natural gas

Figure 6. Reduced demand for primary energy inputs under selected policy scenarios: (a) U.S.: 10\%, (b) U.S.: 75\%, (c) China: 10\%, (d) China: $75 \%$. 

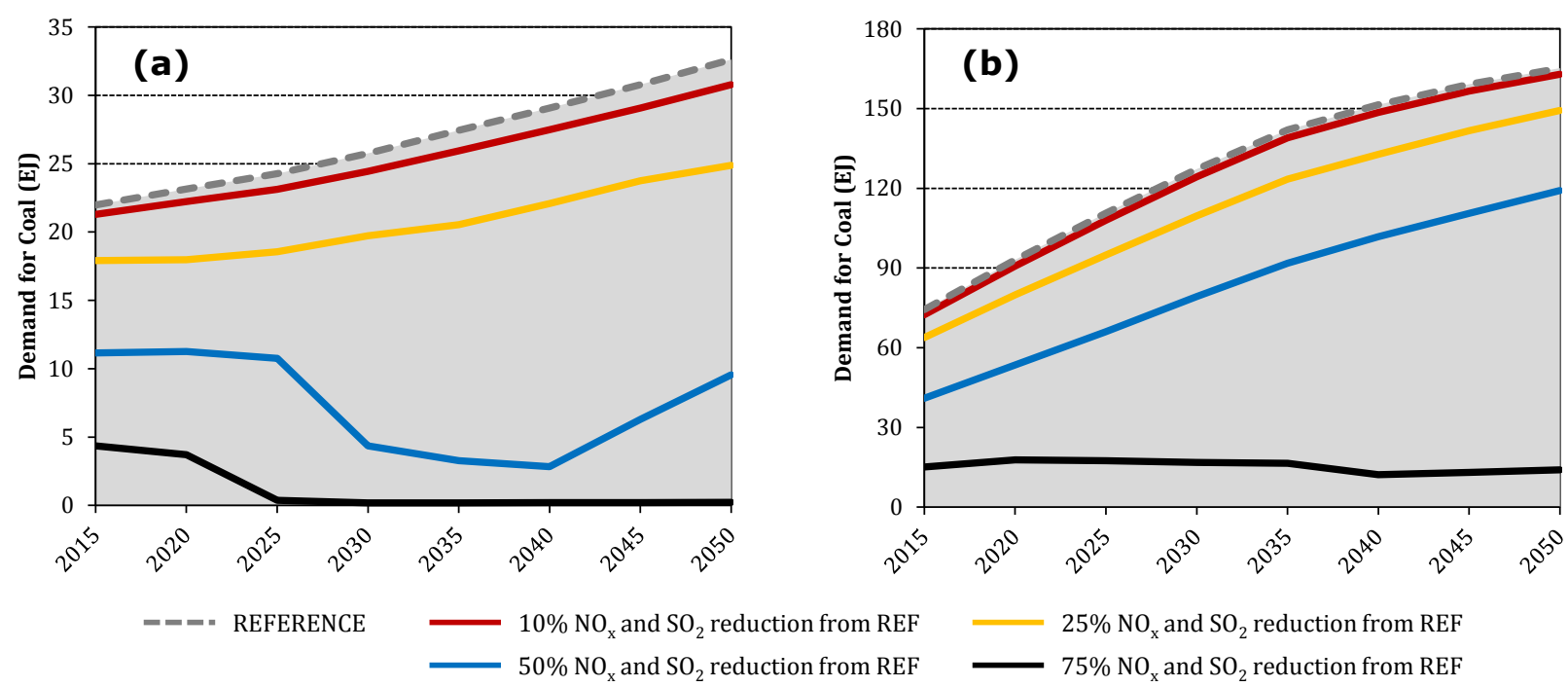

Figure 7. Demand for coal under policy scenarios: (a) U.S., (b) China. 

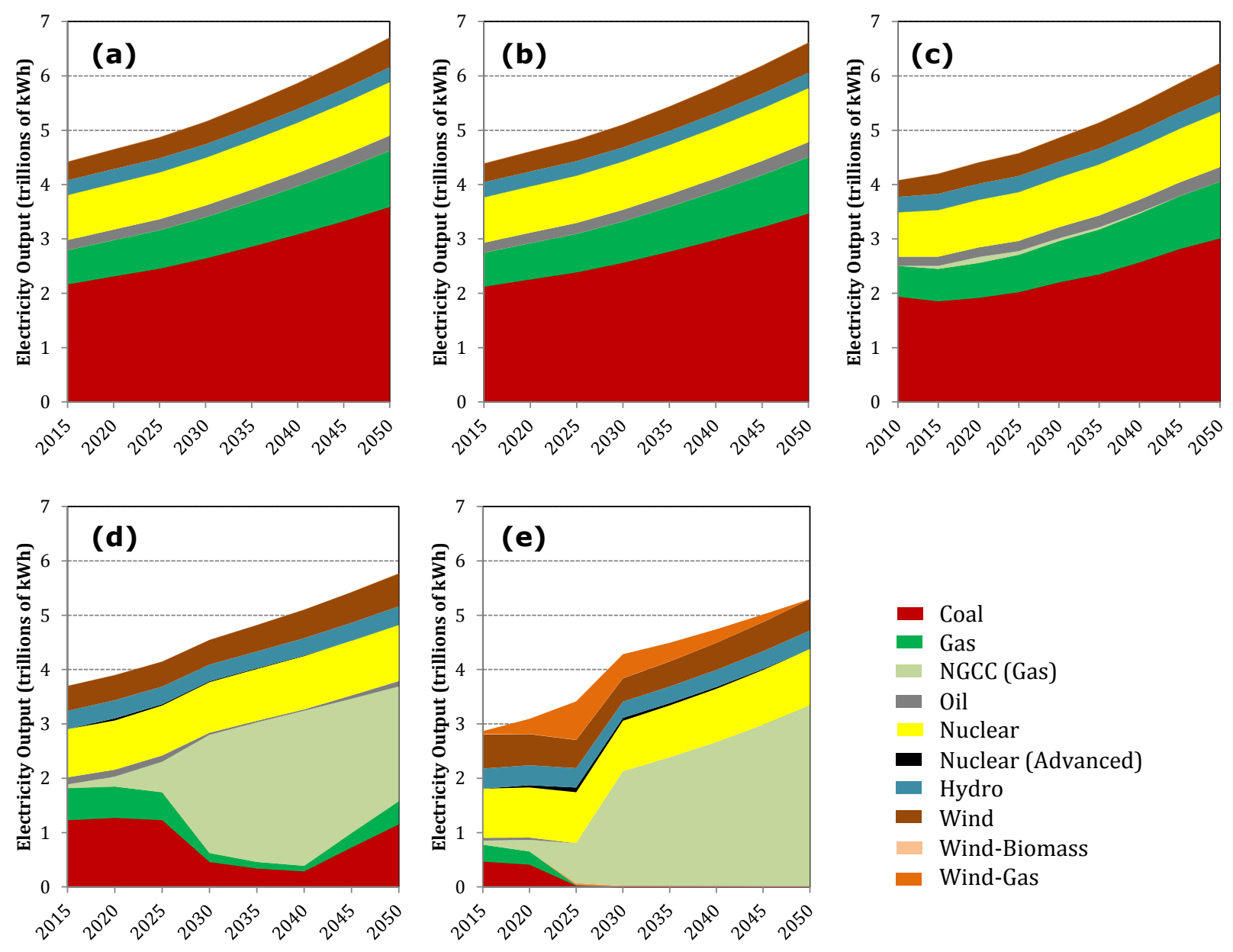

Figure 8. Electricity output mix in the U.S. under pollution-abatement policy: (a) REF, (b) $10 \%$ targets, (c) $25 \%$ targets, (d) $50 \%$ targets, (e) $75 \%$ targets. 

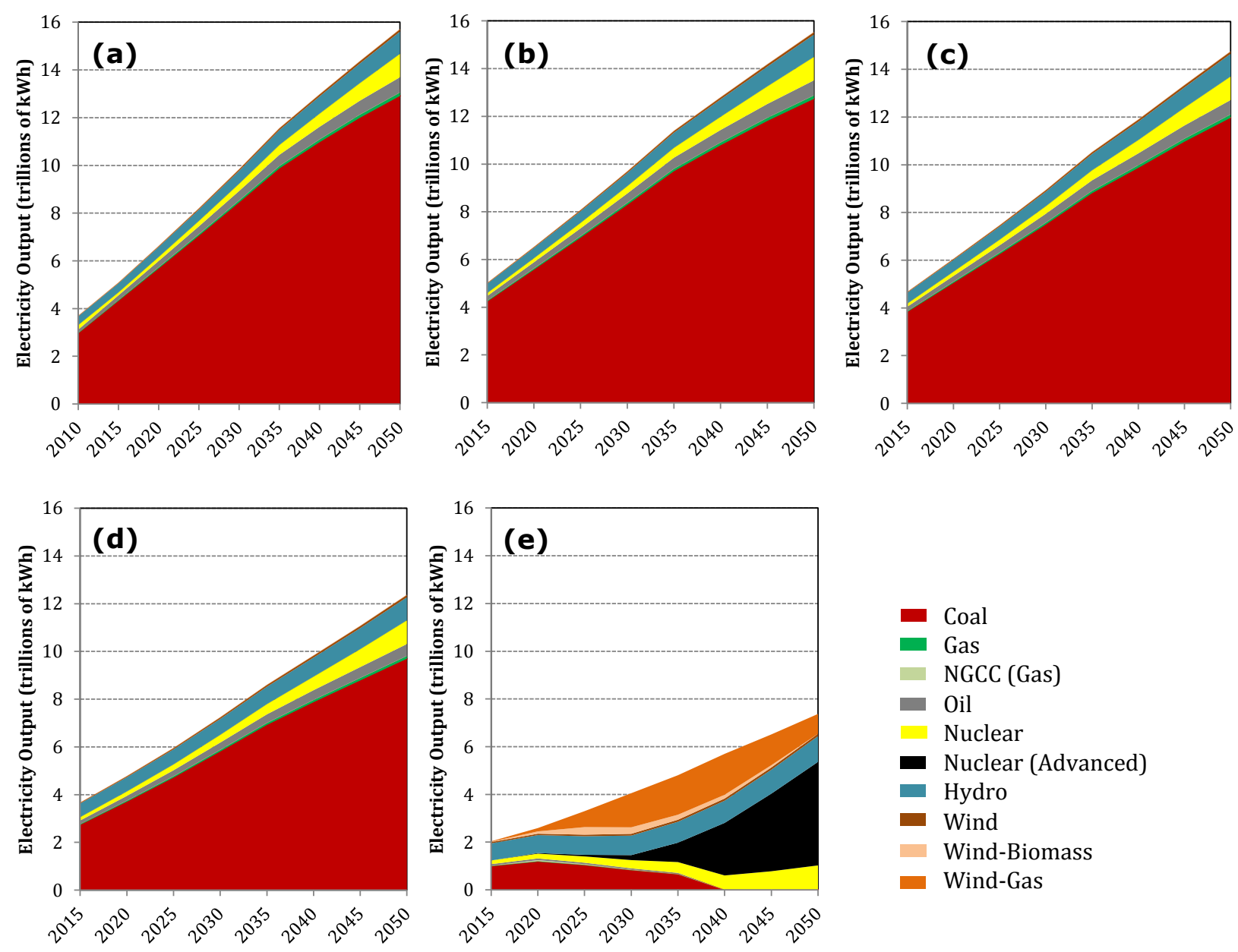

Figure 9. Electricity output mix in China under pollution-abatement policy: (a) REF, (b) $10 \%$ targets, (c) $25 \%$ targets, (d) $50 \%$ targets, (e) $75 \%$ targets. 


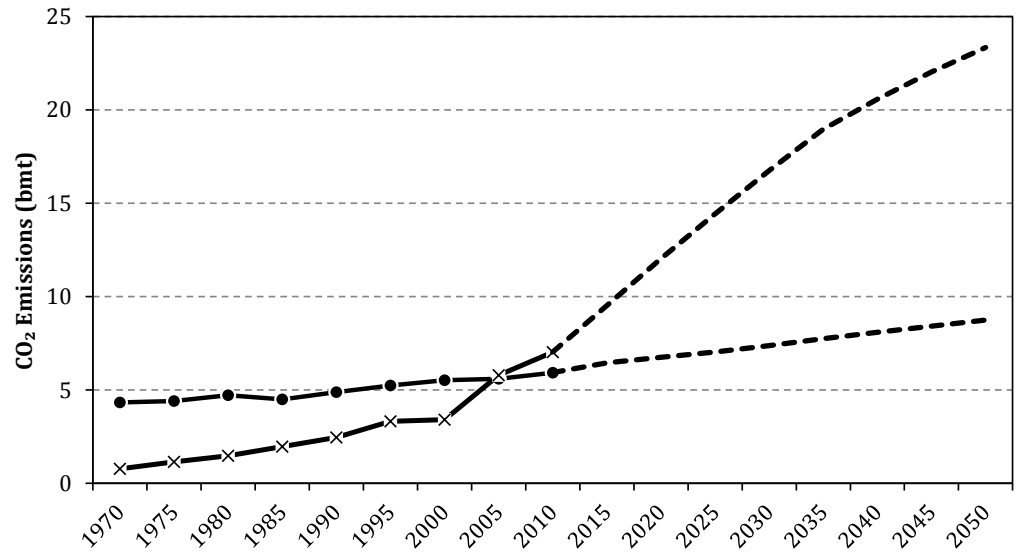

- •- USA-Historical

-x- China-Historical

--ー. REFERENCE

Figure 10. Baseline $\mathrm{CO}_{2}$ emissions schedule. 

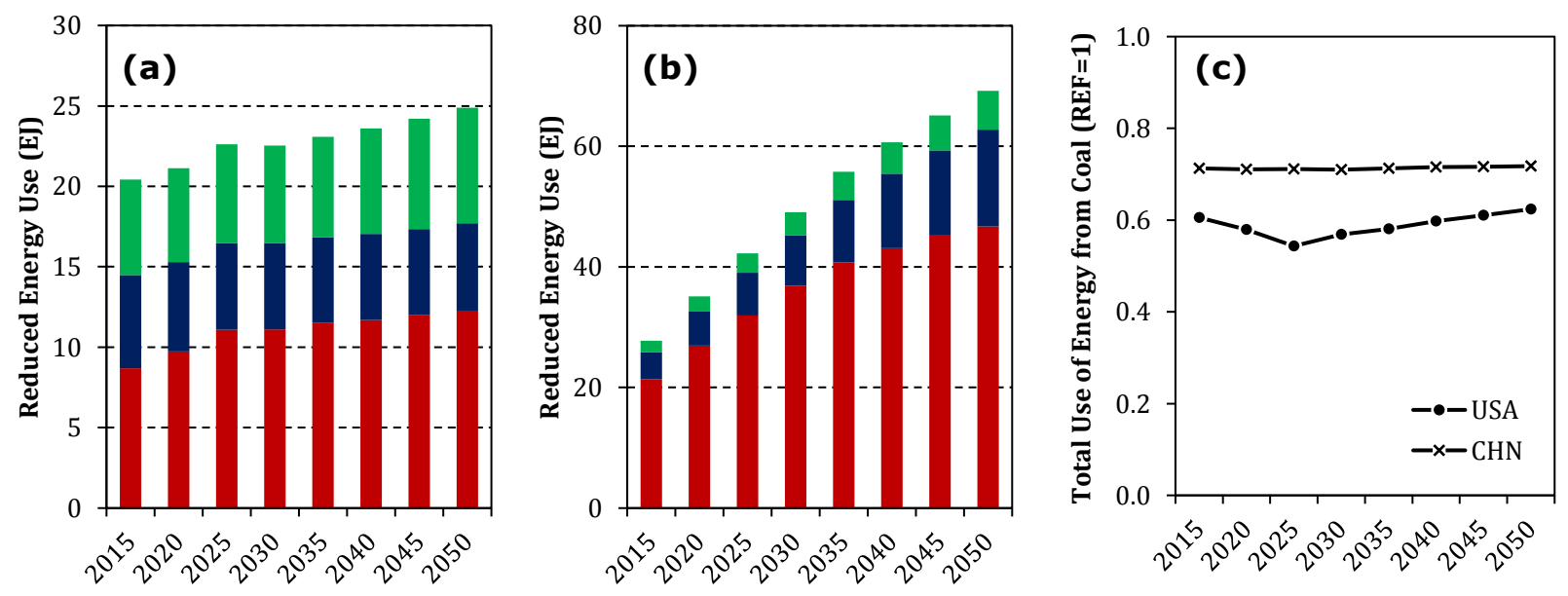

Coal Refined oil Natural gas

Figure 11. Reduced energy use under $25 \% \mathrm{CO}_{2}$ reduction scenario: (a) U.S., (b) China, (c) Total use of coal-based energy relative to the baseline level. 

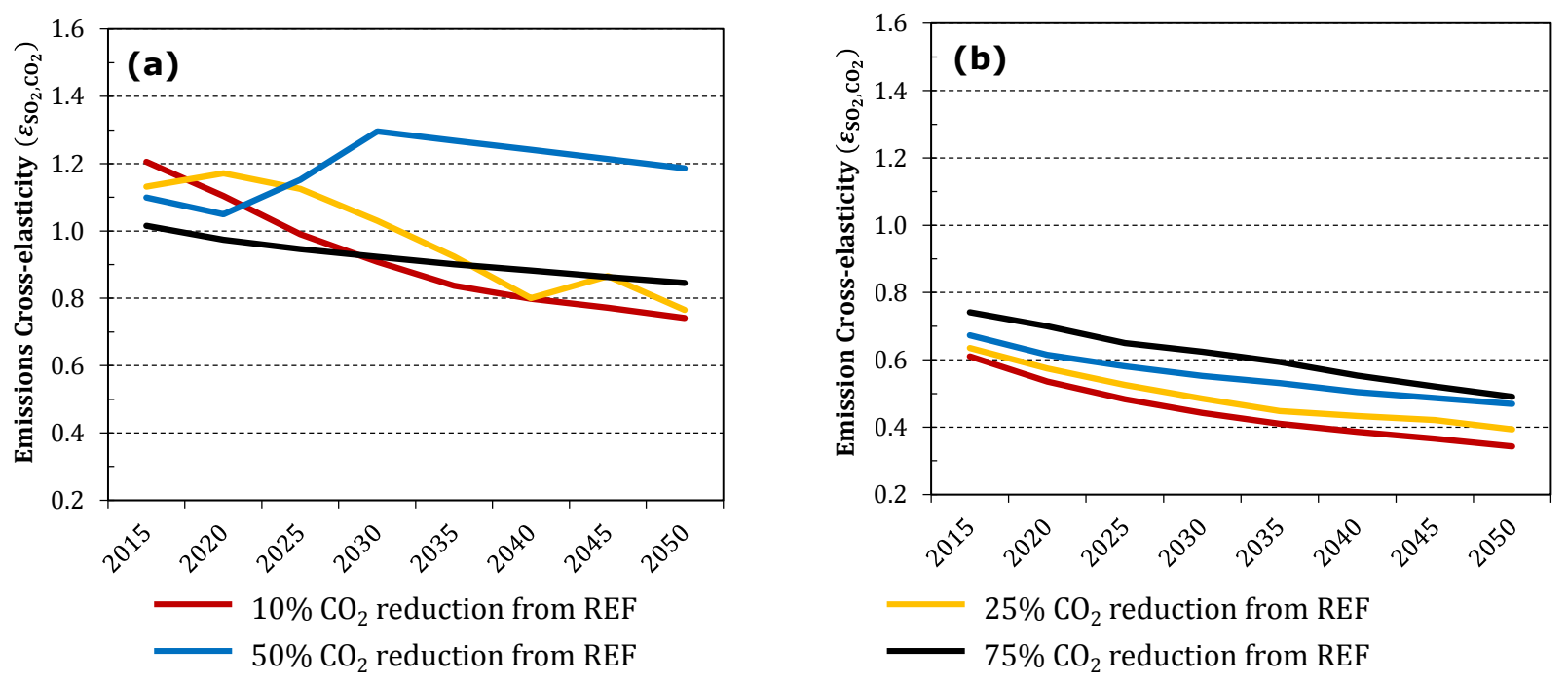

Figure 12. Emissions cross-elasticity $\left(\boldsymbol{\varepsilon}_{\mathrm{SO}_{2}, \mathrm{CO}_{2}}\right)$ by scenario: (a) U.S., (b) China. Graph uses data from Table 6. 

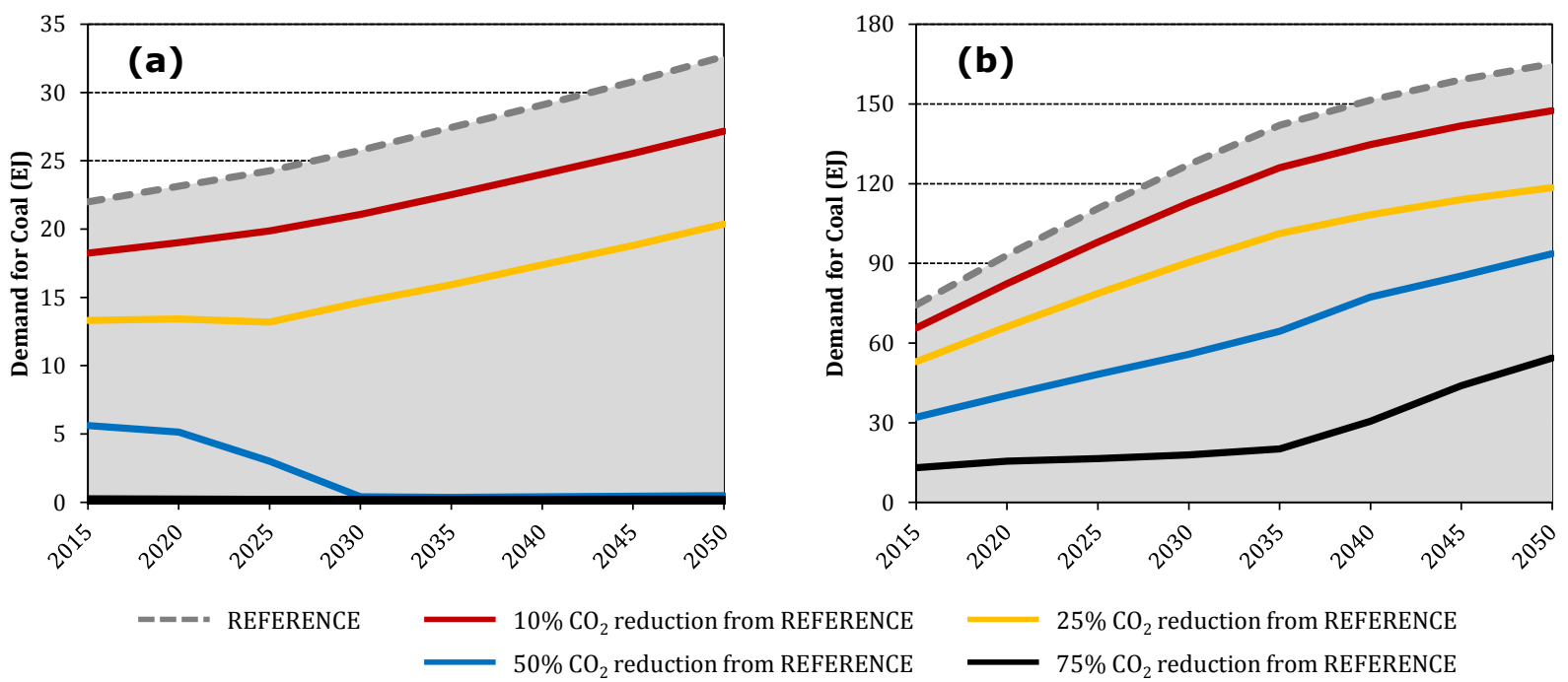

Figure 13. Reduced demand for coal-based energy: (a) U.S., (b) China. 
Targeted

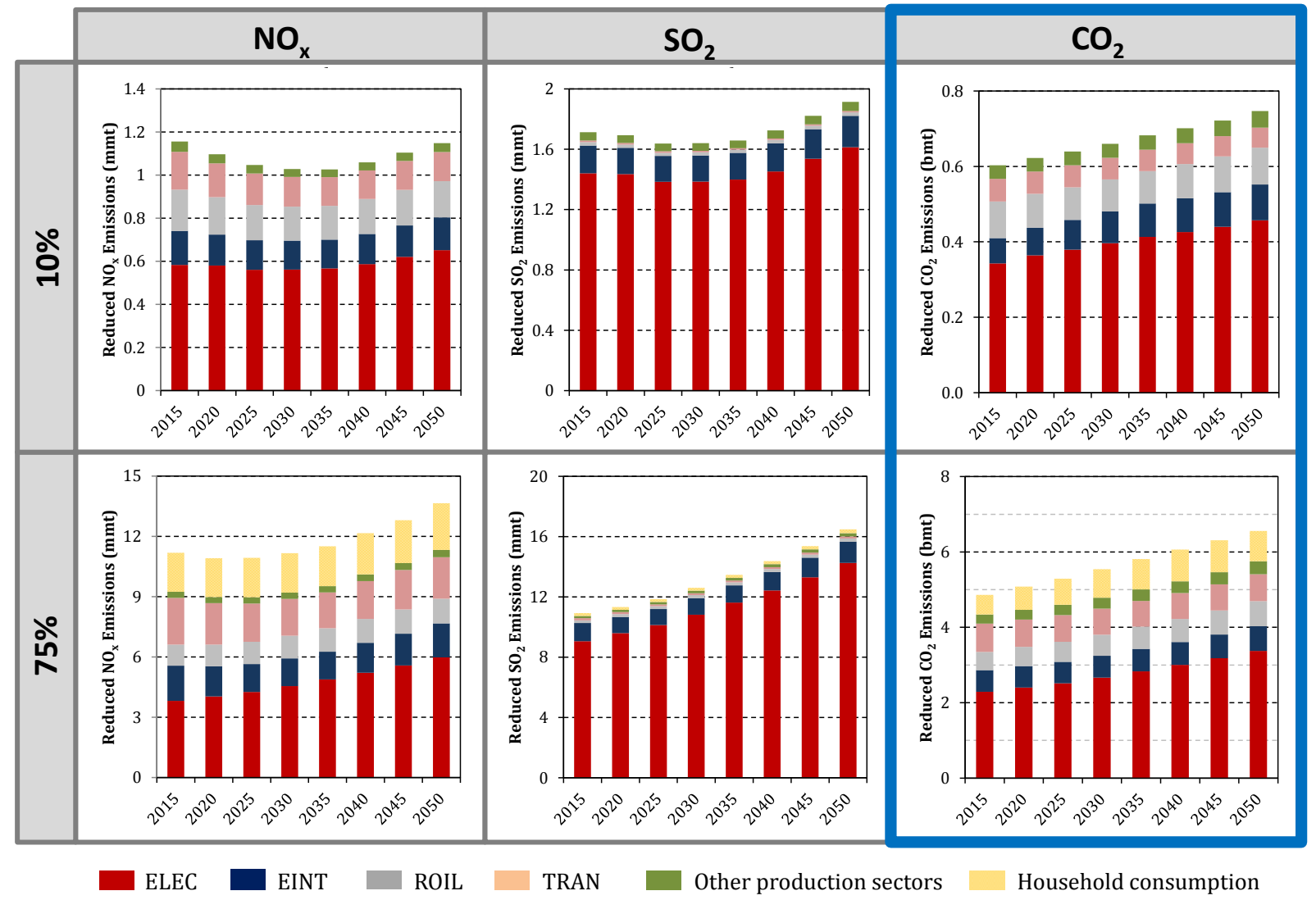

Figure 14. Reduced emissions in the U.S. by gas and sector under $\mathrm{CO}_{2}$ control scenarios. 

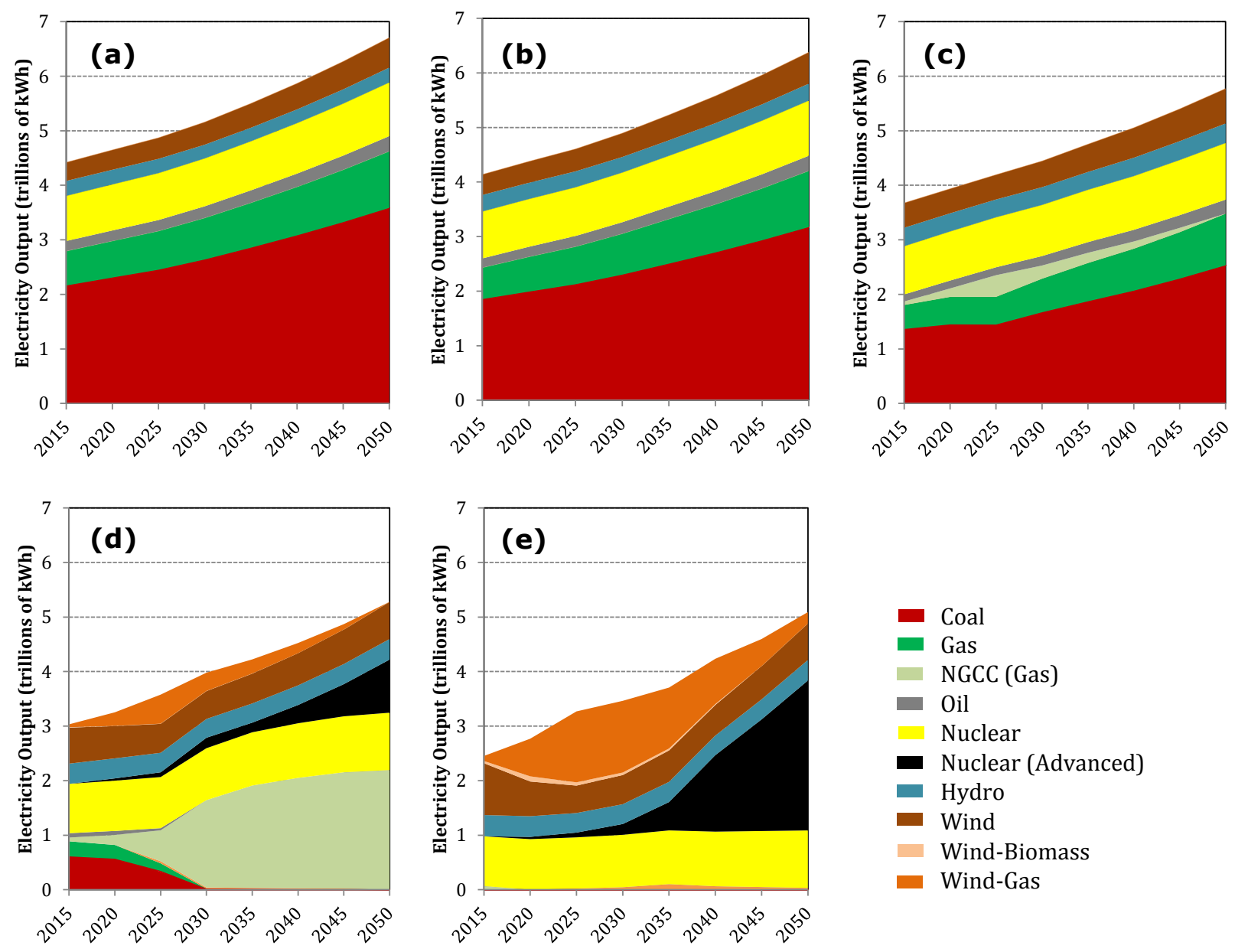

Figure 15. Electricity output mix in the U.S. under carbon-mitigation policy: (a) REF, (b) $10 \%$ targets, (c) $25 \%$ targets, (d) $50 \%$ targets, (e) $75 \%$ targets. 

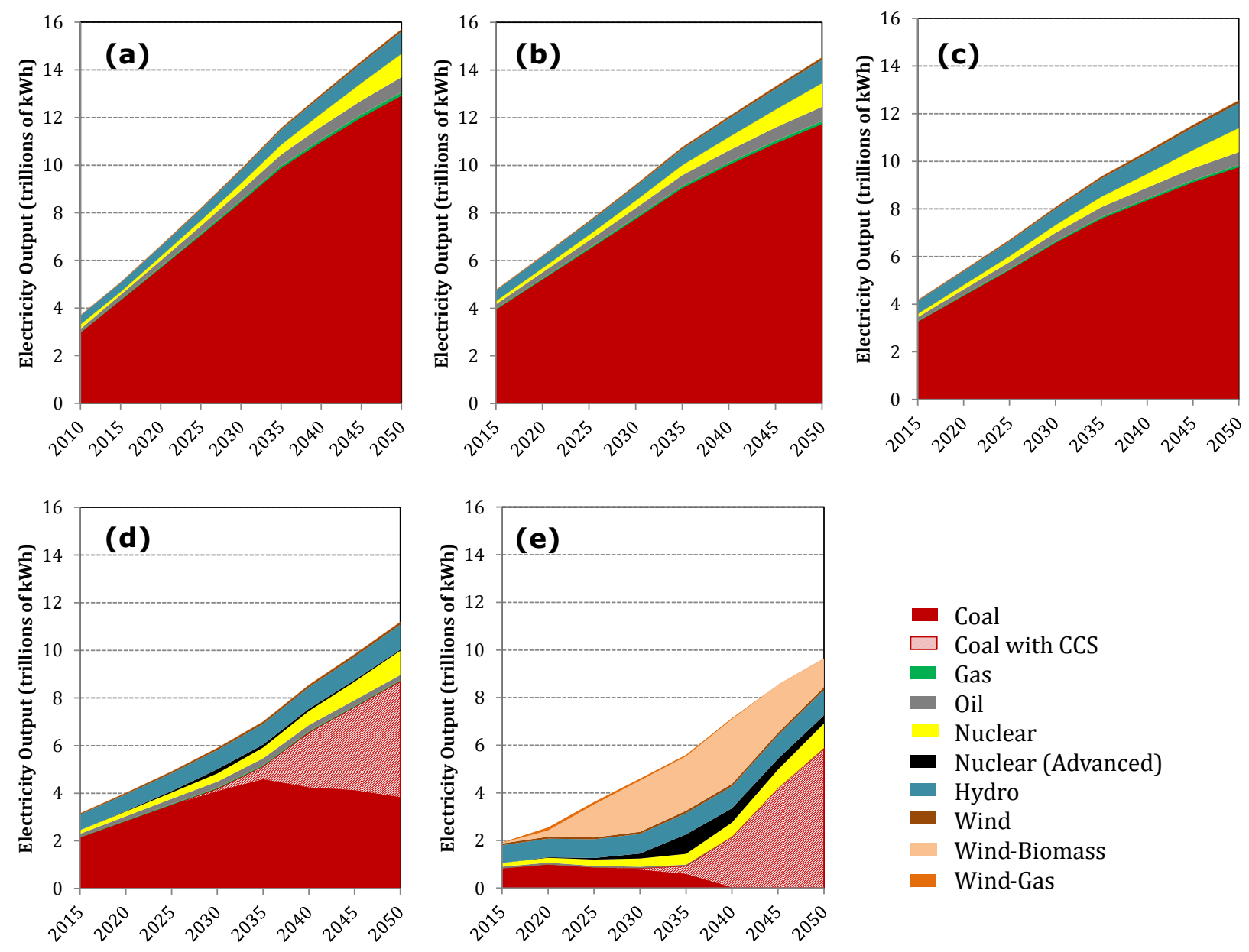

Figure 16. Electricity output mix in China under carbon-mitigation policy: (a) REF, (b) $10 \%$ targets, (c) $25 \%$ targets, (d) $50 \%$ targets, (e) $75 \%$ targets. 
Table 1. Studies of ancillary carbon-mitigation benefits from pollution control.

\begin{tabular}{|c|c|c|c|c|c|}
\hline Study & $\begin{array}{l}\text { City or } \\
\text { Country }\end{array}$ & Sectors & Pollutants & $\begin{array}{l}\text { Policy } \\
\text { Considered }\end{array}$ & $\begin{array}{l}\text { Ancillary } \mathrm{CO}_{2} \text { Benefits } \\
\left(\% \Delta \mathrm{CO}_{2} / \% \Delta \text { Pollution }\right)\end{array}$ \\
\hline $\begin{array}{l}\text { Morgenstern et al. } \\
(2004)\end{array}$ & $\begin{array}{l}\text { Taiyuan } \\
\text { (China) }\end{array}$ & Electric & $\mathrm{SO}_{2}$ & $\begin{array}{l}\text { Shut down small } \\
\text { boilers, switch to } \\
\text { low sulfur fuels }\end{array}$ & $0.76-0.97$ \\
\hline $\begin{array}{l}\text { Xu and Masui } \\
(2009)\end{array}$ & China & All & $\mathrm{SO}_{2}$ & $\begin{array}{l}\text { Emission caps, } \\
\text { energy efficiency, } \\
\text { sulfur tax }\end{array}$ & $0.90-0.97$ \\
\hline Chae (2010) & $\begin{array}{l}\text { Seoul } \\
\text { (Korea) }\end{array}$ & $\begin{array}{l}\text { Transportation } \\
\text { (public buses) }\end{array}$ & $\mathrm{NO}_{x}, \mathrm{PM}_{10}$ & $\begin{array}{l}\text { Switch to low } \\
\text { sulfur fuels }\end{array}$ & $0.14-0.88$ \\
\hline Agee et al. (2012) & U.S. & Electric & $\mathrm{NO}_{x}, \mathrm{SO}_{2}$ & Cap and trade & $\mathrm{n} / \mathrm{a}$ \\
\hline Cao et al. (2012) & China & All & $\mathrm{SO}_{2}$ & Emission caps & 0.23 \\
\hline Nam et al. (2013) & China & All & $\mathrm{NO}_{x}, \mathrm{SO}_{2}$ & Emission caps & $0.41-0.99$ \\
\hline
\end{tabular}


Table 2. Cross-elasticity $\left(\boldsymbol{\varepsilon}_{\mathrm{CO}_{2}, \mathrm{NO}_{\mathrm{x}}}\right)$ when only $\mathrm{NO}_{\mathrm{x}}$ emissions caps are imposed.

\begin{tabular}{|c|c|c|c|c|c|c|c|c|}
\hline & \multicolumn{4}{|c|}{ U.S. } & \multicolumn{4}{|c|}{ China } \\
\hline & $10 \%$ & $25 \%$ & $50 \%$ & $75 \%$ & $10 \%$ & $25 \%$ & $50 \%$ & $75 \%$ \\
\hline 2015 & 0.12 & 0.21 & 0.44 & 0.59 & 0.13 & 0.37 & 0.73 & 0.94 \\
\hline 2020 & 0.15 & 0.25 & 0.48 & 0.62 & 0.12 & 0.36 & 0.74 & 0.94 \\
\hline 2025 & 0.18 & 0.28 & 0.52 & 0.67 & 0.11 & 0.35 & 0.69 & 0.97 \\
\hline 2030 & 0.19 & 0.30 & 0.61 & 0.61 & 0.10 & 0.33 & 0.64 & 0.98 \\
\hline 2035 & 0.21 & 0.32 & 0.65 & 0.61 & 0.09 & 0.30 & 0.58 & 0.99 \\
\hline 2040 & 0.22 & 0.33 & 0.67 & 0.61 & 0.08 & 0.28 & 0.52 & 1.02 \\
\hline 2045 & 0.23 & 0.34 & 0.63 & 0.61 & 0.07 & 0.25 & 0.47 & 1.03 \\
\hline 2050 & 0.23 & 0.34 & 0.60 & 0.61 & 0.06 & 0.22 & 0.42 & 1.03 \\
\hline
\end{tabular}


Table 3. Cross-elasticity $\left(\varepsilon_{\mathrm{CO}_{2}, \mathrm{SO}_{2}}\right)$ when only $\mathrm{SO}_{2}$ emissions caps are imposed.

\begin{tabular}{|c|c|c|c|c|c|c|c|c|}
\hline & \multicolumn{4}{|c|}{ U.S. } & \multicolumn{4}{|c|}{ China } \\
\hline & $10 \%$ & $25 \%$ & $50 \%$ & $75 \%$ & $10 \%$ & $25 \%$ & $50 \%$ & $75 \%$ \\
\hline 2015 & 0.11 & 0.29 & 0.34 & 0.44 & 0.10 & 0.33 & 0.66 & 0.83 \\
\hline 2020 & 0.13 & 0.25 & 0.35 & 0.47 & 0.11 & 0.34 & 0.63 & 0.84 \\
\hline 2025 & 0.15 & 0.33 & 0.35 & 0.47 & 0.11 & 0.35 & 0.60 & 0.87 \\
\hline 2030 & 0.15 & 0.35 & 0.39 & 0.40 & 0.11 & 0.35 & 0.59 & 0.89 \\
\hline 2035 & 0.14 & 0.37 & 0.39 & 0.40 & 0.10 & 0.33 & 0.54 & 0.90 \\
\hline 2040 & 0.13 & 0.39 & 0.50 & 0.40 & 0.10 & 0.31 & 0.49 & 0.92 \\
\hline 2045 & 0.12 & 0.33 & 0.48 & 0.40 & 0.09 & 0.28 & 0.45 & 0.93 \\
\hline 2050 & 0.11 & 0.35 & 0.54 & 0.40 & 0.08 & 0.24 & 0.41 & 0.92 \\
\hline
\end{tabular}


Table 4. Cross-elasticity between $\mathrm{NO}_{\mathrm{x}}$ and $\mathrm{CO}_{2}\left(\boldsymbol{\varepsilon}_{\mathrm{NO}_{\mathrm{x}}, \mathrm{CO}_{2}}\right)$.

\begin{tabular}{|c|c|c|c|c|c|c|c|c|}
\hline & \multicolumn{4}{|c|}{ U.S. } & \multicolumn{4}{|c|}{ China } \\
\hline & $10 \%$ & $25 \%$ & $50 \%$ & $75 \%$ & $10 \%$ & $25 \%$ & $50 \%$ & $75 \%$ \\
\hline 2015 & 0.78 & 0.79 & 0.82 & 0.85 & 0.45 & 0.49 & 0.55 & 0.65 \\
\hline 2020 & 0.68 & 0.73 & 0.73 & 0.77 & 0.40 & 0.45 & 0.51 & 0.61 \\
\hline 2025 & 0.60 & 0.67 & 0.68 & 0.72 & 0.37 & 0.42 & 0.49 & 0.55 \\
\hline 2030 & 0.54 & 0.61 & 0.70 & 0.68 & 0.35 & 0.39 & 0.47 & 0.53 \\
\hline 2035 & 0.49 & 0.56 & 0.68 & 0.65 & 0.33 & 0.37 & 0.45 & 0.50 \\
\hline 2040 & 0.47 & 0.51 & 0.66 & 0.63 & 0.32 & 0.36 & 0.41 & 0.45 \\
\hline 2045 & 0.45 & 0.52 & 0.64 & 0.61 & 0.31 & 0.35 & 0.39 & 0.43 \\
\hline 2050 & 0.43 & 0.48 & 0.61 & 0.60 & 0.29 & 0.33 & 0.37 & 0.41 \\
\hline
\end{tabular}


Table 5. Cross-elasticity between $\mathrm{SO}_{2}$ and $\mathrm{CO}_{2}\left(\boldsymbol{\varepsilon}_{\mathrm{SO}_{2}, \mathrm{CO}_{2}}\right)$.

\begin{tabular}{|c|c|c|c|c|c|c|c|c|}
\hline & \multicolumn{4}{|c|}{ U.S. } & \multicolumn{4}{|c|}{ China } \\
\hline & $10 \%$ & $25 \%$ & $50 \%$ & $75 \%$ & $10 \%$ & $25 \%$ & $50 \%$ & $75 \%$ \\
\hline 2015 & 1.21 & 1.13 & 1.10 & 1.02 & 0.61 & 0.64 & 0.67 & 0.74 \\
\hline 2020 & 1.10 & 1.17 & 1.05 & 0.97 & 0.54 & 0.57 & 0.61 & 0.70 \\
\hline 2025 & 0.99 & 1.12 & 1.15 & 0.95 & 0.48 & 0.53 & 0.58 & 0.65 \\
\hline 2030 & 0.91 & 1.03 & 1.30 & 0.92 & 0.44 & 0.48 & 0.55 & 0.62 \\
\hline 2035 & 0.84 & 0.92 & 1.27 & 0.90 & 0.41 & 0.45 & 0.53 & 0.59 \\
\hline 2040 & 0.80 & 0.80 & 1.24 & 0.88 & 0.39 & 0.43 & 0.50 & 0.55 \\
\hline 2045 & 0.77 & 0.87 & 1.21 & 0.86 & 0.37 & 0.42 & 0.49 & 0.52 \\
\hline 2050 & 0.74 & 0.77 & 1.19 & 0.85 & 0.34 & 0.39 & 0.47 & 0.49 \\
\hline
\end{tabular}

